\title{
Mitochondrial Fatty Acid Oxidation in Obesity
}

\author{
Dolors Serra, Paula Mera, Maria Ida Malandrino, Joan Francesc Mir, and Laura Herrero
}

\begin{abstract}
Significance: Current lifestyles with high-energy diets and little exercise are triggering an alarming growth in obesity. Excess of adiposity is leading to severe increases in associated pathologies, such as insulin resistance, type 2 diabetes, atherosclerosis, cancer, arthritis, asthma, and hypertension. This, together with the lack of efficient obesity drugs, is the driving force behind much research. Recent Advances: Traditional anti-obesity strategies focused on reducing food intake and increasing physical activity. However, recent results suggest that enhancing cellular energy expenditure may be an attractive alternative therapy. Critical Issues: This review evaluates recent discoveries regarding mitochondrial fatty acid oxidation (FAO) and its potential as a therapy for obesity. We focus on the still controversial beneficial effects of increased FAO in liver and muscle, recent studies on how to potentiate adipose tissue energy expenditure, and the different hypotheses involving FAO and the reactive oxygen species production in the hypothalamic control of food intake. Future Directions: The present review aims to provide an overview of novel anti-obesity strategies that target mitochondrial FAO and that will definitively be of high interest in the future research to fight against obesity-related disorders. Antioxid. Redox Signal. 19, 269-284.
\end{abstract}

\section{Obesity: Molecular and Pathophysiological Features}

$\mathrm{O}$ BESITY IS DEFINED AS abnormal or excessive fat accumulation in the adipose tissue and other organs. The World Health Organization (WHO) defines overweight as a body mass index (BMI; calculated as weight $[\mathrm{kg}]$ divided by height squared $\left[\mathrm{m}^{2}\right]$ ) equal to or greater than $25 \mathrm{~kg} / \mathrm{m}^{2}$ and obese as a BMI equal to or greater than $30 \mathrm{~kg} / \mathrm{m}^{2}$ (137). Current lifestyle trends and continuous nutrient excess are causing obesity to increase at alarming rates, especially in young people. There are more than 500 million obese people worldwide and, more importantly, overweight and obesity are the fifth leading risk for death globally (137). Humanity is facing a new epidemic already dubbed "Prosperity's Plague" (160). Therefore, significant research is needed in the race to find effective therapies and to minimize the enormous costs of the related healthcare.

Weight gain is influenced by several factors, such as genetics, maternal and perinatal environment, energy-dense diets, and sedentary lifestyle (3). Of great concern are the concurrent and parallel increases in the prevalence of pathological conditions associated with obesity, which include insulin resistance, type 2 diabetes, cardiovascular disease, nonalcoholic fatty liver, polycystic ovary syndrome, asthma, Alzheimer's disease, and some forms of cancer. Elucidating the causes involved in the pathophysiology of obesity-related disorders is one of the most critical endeavors in modern medical research.

Several mechanisms have emerged in the past two decades, during which obesity and especially its connection to insulin resistance have become a top-interest research topic being studied by leading groups in the field.

\section{Ectopic-fat deposition}

When the adipose tissue cannot store excess fat, lipids accumulate inappropriately in the liver, muscle, and pancreas. This lipotoxic environment, mainly mediated by diacylglycerols (DAGs), blocks correct glucose transport and insulin signaling (145). Thus, it has been postulated that any strategy that could block the entry of fatty acids (FAs) into the cell, promote fatty acid oxidation (FAO), or convert DAGs into triglycerides (TGs) could prevent insulin resistance (160).

\section{Inflammation}

The pathophysiology of obesity-induced insulin resistance has also been correlated with an increase in circulation and tissue inflammation originating in the adipocyte damage and infiltration of immune cells $(107,151)$. As fat accumulates in adipose tissue, adipocytes overcome their healthy size limit $(157,169)$ and release inflammatory cytokines and molecules

Department of Biochemistry and Molecular Biology, Facultat de Farmàcia, Universitat de Barcelona, Institut de Biomedicina de la Universitat de Barcelona (IBUB), and CIBER Fisiopatología de la Obesidad y la Nutrición (CIBEROBN), Instituto de Salud Carlos III, Barcelona, Spain. 
known as adipokines. The excessive accumulation of lipids in the adipose tissue leads to adipocyte hypoxia (73), endoplasmic reticulum (ER) stress (132), and cell death, and causes FA spillover (145). Infiltrated immune cells also contribute to this chronic low-grade inflammatory milieu, whereby the increase in inflammatory cytokines causes insulin resistance elsewhere in the body. Thus, anti-inflammatory strategies become central as possible new treatments of insulin resistance and other complications of obesity (56).

\section{ER stress}

The fundamental role of ER is the integration of multiple metabolic signals and the maintenance of cell homeostasis (26, 58). Under stress conditions that challenge its function, ER triggers an adaptive response called uncoupled protein response (UPR) $(97,178)$. To resolve ER stress, UPR promotes a decrease in protein synthesis, and at the same time, an increase in protein degradation and chaperone production for protein folding. During the chronic energy surplus associated with obesity, ER cannot recover its normal function and UPR activation contributes to the development of insulin resistance through several mechanisms, such as JNK-Ap1 and NF-K $\beta$ IKK signaling pathways, inflammation, and oxidative stress (74).

\section{Food intake}

The central nervous system, specifically the hypothalamus, is of crucial importance in obesity-induced pathologies, since it plays a major role in the control of food intake and regulation of body weight (177). The discovery of leptin was a major breakthrough for our current knowledge of energy homeostasis (179). This adipocyte-secreted hormone acts on the hypothalamus to inhibit food intake and control body weight and has proved essential in the interaction between the brain and other organs in obesity-related disorders (51). The alteration of the circadian rhythm has also been associated with an increased risk of obesity $(63,76)$, proving that it is not only what you eat, but also when you eat it. Thus, advances in understanding the molecular mechanisms linking circadian rhythms and metabolism may provide new therapies for obesity and other pathologies associated with the disruption of normal sleep-wake cycles.

\section{Lack of Efficacy of Current Anti-Obesity Drugs}

Obesity develops when energy intake exceeds energy expenditure. Thus, any treatment for obesity-induced disorders must reduce energy intake, increase energy expenditure, or have an effect on both. Attempting to lose weight only by caloric restriction comes up against the problem that mammals have evolved mechanisms to store energy to survive during periods of starvation. Such homeostatic mechanisms increase caloric efficiency, thus making further weight loss even more difficult. In recent years, several anti-obesity drugs designed to limit energy intake have been withdrawn from the market due to serious adverse effects (i.e., fenfluramine, dexfenfluramine, sibutramine, and rimonabant) (36). Nowadays, only two drugs are approved specifically for weight loss by the US Food and Drug Administration (FDA): the lipaseinhibitor Orlistat that is also approved by the European Medicines Agency (EMA), but has a limited long-term effectiveness (36), and the recently approved serotonergic Lorca-
serin-Belviq $(84,126)$. Thus, more efforts are needed to develop new anti-obesity agents. In this regard, strategies designed to increase lipid mobilization and oxidation could be very useful in the treatment of obesity and associated diseases.

\section{Mitochondrial FAO and Bioenergetics}

Hormones, such as insulin, glucagon, and noradrenaline, control the extracellular uptake and intracellular release of the main cell fuels; namely, carbohydrates and FAs. Once inside the cell, FAs are esterified, metabolized to lipid second messengers, or $\beta$-oxidized in mitochondria. The first step of the oxidative pathway is the transport of long-chain FAs (LCFAs) into the mitochondrial matrix (Fig. 1). This step is controlled by the carnitine palmitoyltransferase (CPT) system, which consists of three proteins: CPT1, acylcarnitine translocase (CACT), and CPT2 (109). Malonyl-CoA, a molecule derived from glucose metabolism and the first intermediate in lipogenesis, regulates FAO by inhibiting CPT1, thus making this enzyme the rate-limiting step in mitochondrial oxidation of FAs. Mammal tissues express three isoforms of CPT1: CPT1A (41) (liver), CPT1B (175) (muscle and heart), and CPT1C (138) (brain). Acetyl-CoA carboxylase (ACC), which controls the synthesis of malonyl-CoA; malonyl-CoA decarboxylase

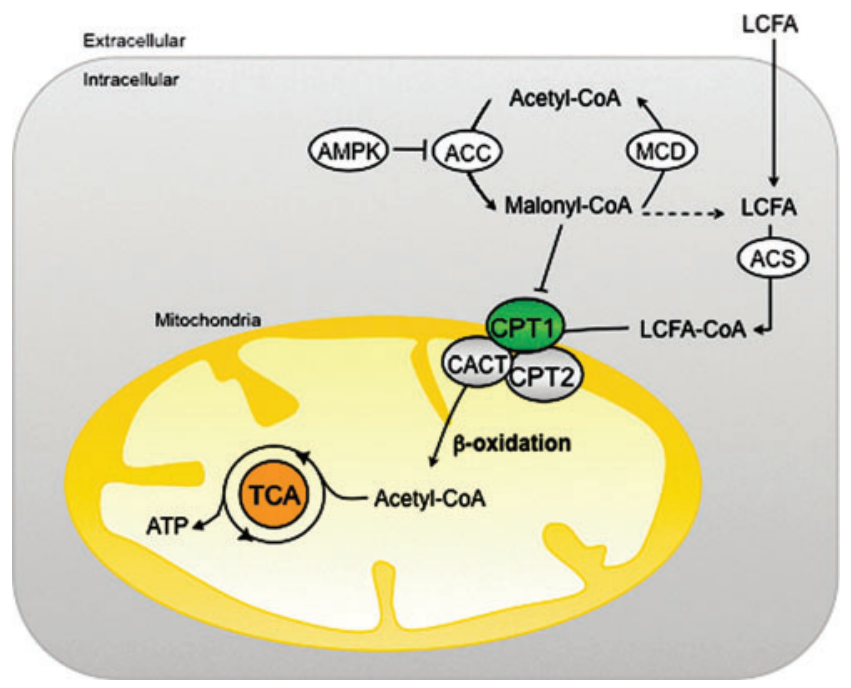

FIG. 1. Mitochondrial fatty acid oxidation (FAO). Longchain fatty acid (LCFA) catalysis implies activation by acylCoA synthase (ACS) of LCFAs into LCFA-CoA, which is a substrate for the mitochondrial carnitine palmitoyltransferase 1 (CPT1) enzyme. The CPT system, which includes CPT1, acylcarnitine translocase (CACT), and CPT2, allows LCFACoA to enter the mitochondrial matrix, via transesterification reactions, to then be $\beta$-oxidized. CPT1 is the rate-limiting enzyme in FAO since its activity is tightly regulated by the glucose-derived malonyl-CoA, generated by acetyl-CoA carboxylase (ACC) during fatty acid (FA) de novo formation (in energetically abundant situations) or degraded by malonyl-CoA decarboxylase (MCD) in a process regulated by AMP-activated protein kinase (AMPK). Acetyl-CoA generated in FAO eventually enters the tricarboxylic acid (TCA) cycle to obtain reductive power for cellular respiration and produce ATP. To see this illustration in color, the reader is referred to the web version of this article at www liebertpub.com/ars 
(MCD), which catalyzes malonyl-CoA degradation; and CPT1, which is regulated by malonyl-CoA, are components of a metabolic signaling network that perceives the level of fuel stimuli (109).

One of the main regulators of this network is the AMPactivated protein kinase (AMPK). This protein is the downstream element of a kinase cascade, activated by its phosphorylation in the Thr172 residue of the catalytic subunit (174). In general, AMPK inhibits ATP-consuming processes, while activating catabolic pathways. Active AMPK phosphorylates and inhibits ACC and reduces the expression of FA synthase, thus decreasing the flux of substrates in the FA anabolic pathway (176). In consequence, the reduction in malonylCoA levels leads to an increase in CPT1 activity and FAO.

The regulation of AMPK by members of the sirtuin family of $\mathrm{NAD}^{+}$-dependent protein deacetylases and ADP-ribosyltransferases (sirtuins) has been reported (94). Sirtuin 1 (SIRT1) and SIRT3 stimulate AMPK by deacetylating its upstream activator, kinase LKB1 $(94,135)$. In turn, the AMPK activity leads to an increase in $\mathrm{NAD}^{+}$levels, thereby promoting deacetylation/activation of other SIRT1 targets involved in FAO, like peroxisome proliferator-activated receptor $\gamma$ coactivator- $1 \alpha$ (PGC- $1 \alpha$ ) (18). In recent years, sirtuins have emerged as critical modulators of lipid metabolism and specifically of FAO. In mammals, the seven identified members of the sirtuin family are differentially located within the cell: SIRT1, 6 and 7 are mainly located in the nucleus; SIRT3, 4 and 5 are located in the mitochondria; and SIRT2 is a cytosolic protein (111). In specific tissues, sirtuins act on different targets promoting FAO (liver and skeletal muscle [SkM]), mitochondrial respiration (brown adipose tissue [BAT]), lipolysis (white adipose tissue [WAT]), and food intake (hypothalamus) (148).

Energy flow in living cells (bioenergetics) takes place mainly in mitochondria. Energy is obtained from FAs and other nutrients in the form of ATP-the chemical currency of life-through the tricarboxylic acid (TCA) cycle, and the electron transport chain (ETC) in a process known as oxidative phosphorylation (162) (Fig. 2). This process is the main source of reactive oxygen species (ROS) in the cell. In the ETC, the energy of electrons from $\mathrm{NADH}$ and $\mathrm{FADH}_{2}$ is used to pump protons $\left(\mathrm{H}^{+}\right)$from the mitochondrial matrix to the intermembrane space and generate the electrochemical gradient necessary for ATP synthesis. However, when these electrons escape the ETC, ROS are produced in the mitochondria. Even under physiological conditions, the incomplete electron transfer to $\mathrm{O}_{2}$, resulting in ROS production, occurs with $0.2 \%-$ $2 \%$ of oxygen molecules (21). Mitochondrial ROS production is highly regulated and important for various cell functions, as ROS can act as signaling molecules. However, high ROS levels are associated with significant cell damage and mitochondrial dysfunction in a process known as oxidative stress (122), usually associated with the etiology of obesity, insulin resistance, and type 2 diabetes (67).

In the mitochondria, the ETC complexes remain electronbounded when the proton gradient between the mitochondrial matrix and the intermembrane space is high, preventing the outward pumping of $\mathrm{H}^{+}$and increasing ROS production. Mitochondrial uncoupling proteins (UCPs) uncouple ATP production from mitochondrial respiration, thereby reducing the $\mathrm{H}^{+}$gradient across the inner mitochondrial membrane and relieving the formation of ROS (106). In BAT, UCP1 dis-

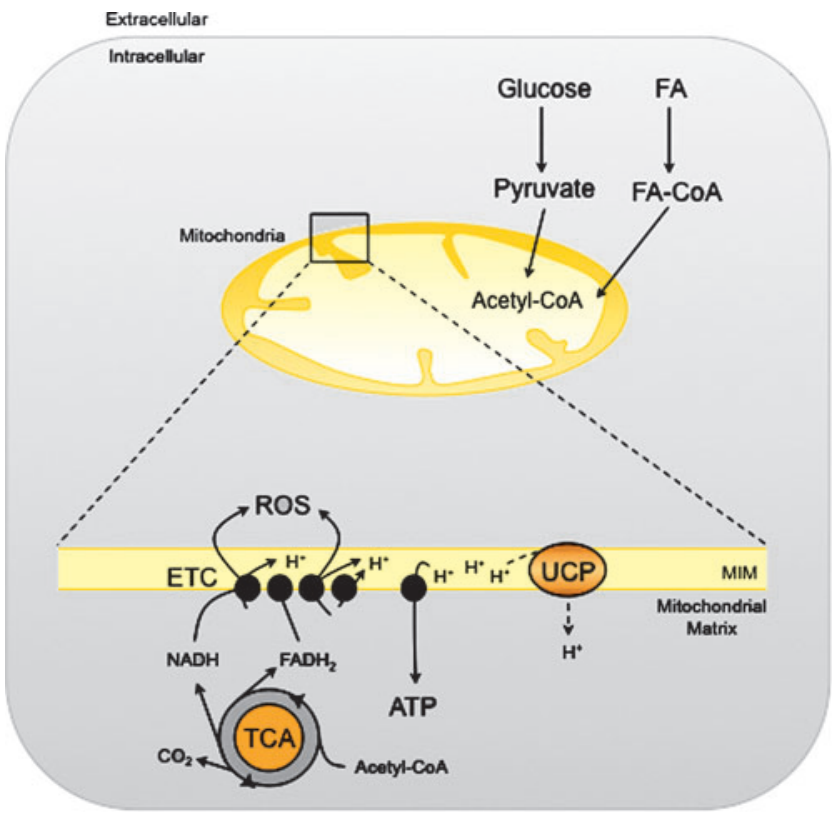

FIG. 2. Bioenergetics and mitochondrial metabolism. The mitochondrial fuels, glucose, and FAs, are converted to acetyl-CoA, which can be further metabolized to obtain energy. The TCA cycle generates protons $\left(\mathrm{H}^{+}\right)$and electrons that are carried by NADH and FADH to the electron transport chain (ETC), where the protons are transported to the mitochondrial intermembrane (MIM) space to generate energy as ATP. Highly reactive electrons may leak from the ETC and generate reactive oxygen species (ROS), which could act physiologically as signaling molecules, but can also cause significant cellular damage when overproduced. Uncoupling proteins (UCPs) dissipate the proton gradient and scavenge ROS accumulation, thus dissipating energy as heat. To see this illustration in color, the reader is referred to the web version of this article at www.liebertpub.com/ars

sipates energy as heat and plays a key role in adaptive thermogenesis. In other tissues, the UCP homologues (UCP2, 3, and 4) affect ROS production and have crucial roles in energy homeostasis (106).

\section{The Central Role of Liver in Obesity}

\section{Fatty liver and nonalcoholic steatohepatitis}

The liver plays a central role in both energy expenditure and lipid/glucose homeostasis. In conditions associated with prolonged excess of energy or impaired FA metabolism, the liver stores considerable amounts of lipids in a process that leads to nonalcoholic fatty liver disease (NAFLD). A hallmark of NAFLD is the accumulation of hepatic TGs, which originate in the increased availability of free FAs (FFAs; circulating and from de novo lipogenesis), altered FAO and inadequate synthesis and export of VLDL $(37,55)$. The imbalance between these inputs and outputs results in lipid accumulation in hepatocytes, which causes hepatosteatosis and insulin resistance. The progression of a more severe liver disease triggers nonalcoholic steatohepatitis (NASH), a serious condition of inflamed fatty liver that can further progress to liver fibrosis and cirrhosis $(32,155)$. The pathogenesis of NAFLD in human and animal models has been reviewed in seminal articles (27, 161). The mechanisms underlying NAFLD to NASH 
progression are not completely understood. However, the alteration of FA metabolism and ROS production, which lead to mitochondrial dysfunction, and the induction of proinflammatory cytokines and fibrosis have emerged as key components that ultimately cause this liver disease (47).

\section{Alterations of mitochondrial FAO and ROS production}

Mitochondria play a vital role in the oxidation of FAs and ROS production. In the liver, mitochondrial FAO results either in complete oxidation to carbon dioxide or in partial oxidation to ketone bodies, which are exported to provide fuel for other tissues. The key step is catalyzed by CPT1A (109). Data on the rates of mitochondrial FAO and CPT1A activity in NAFLD/NASH are not conclusive, possibly because of the use of different models and parameters. In vitro and in vivo studies of liver or hepatocytes exposed to high FFA concentrations show both increased $(25,44,112,116)$ and decreased (43) mitochondrial FAO. Similarly controversial results were obtained with CPT1A expression and activity. An increase in CPT1A expression has been reported in several rodent models $(14,134)$. However, a considerable decrease in the expression of this enzyme was observed in NAFLD patients (123). Several mechanisms may explain these controversial data: (i) the variation of malonyl-CoA levels that depend on the expression and activity of AAC/MCD enzymes $(24,39)$; (ii) the loss of CPT1 sensitivity to malonyl-CoA, which alters CPT1 activity $(29,133)$; and (iii) the increased pool of FFAs or lipid derivatives in hepatocytes may activate transcription factors, such as PPARs (PPAR $\alpha, \operatorname{PPAR} \beta / \delta)$, which in turn may enhance CPT1 expression and FAO $(19,20,22,83)$. However, the transcriptional effect of PPAR $\alpha$ on liver CPT1 remains controversial, since some studies have suggested that long-chain FFA regulates CPT1 expression through a PPAR $\alpha$-independent pathway $(96,101)$. Interestingly, another mechanism that modulates the CPT1 activity has recently been proposed (150). In this study, a NASH rat model fed a methionine-cholinedeficient diet had a notable reduction in CPT1A activity and mitochondrial FAO despite increased CPT1A mRNA expression. The formation of a 4-hydroxynonenal-CPT1 adduct caused by lipid peroxidation as a consequence of ROS overproduction is the main cause of impaired FAO and lipid removal from hepatocytes. ROS can attack polyunsaturated FAs, initiating lipid peroxidation and the formation of aldehyde by-products (ahydroxy-2-nonenal [HNE] and malondialdehyde [MDA]), which have longer half-lives than ROS and are able to spread from their site of origin to reach distant intracellular and extracellular targets, thereby amplifiying the effects of oxidative stress $(44,170)$. The observations listed above suggest that CPT1 overexpression and increased CPT1 activity occur in liver during the onset of steatosis as a mechanism to compensate for increased FA levels. Accelerated mitochondrial FAO might cause excessive electron flux in the ETC and ROS overproduction. As lipids, proteins, and mitochondrial DNA are the main ROS targets, increased ROS might initiate lipid peroxidation, damage mitochondrial DNA and proteins, and alter mitochondrial morphology and function. The post-translational modifications of CPT1 caused by lipid peroxidation could, subsequently, decrease CPT1 activity and reverse initially activated FAO. This notion raises the question of whether interventions aimed at promoting mitochondrial FAO in liver would be beneficial to the treatment of NAFLD/NASH.

Several strategies have been used to promote FAO, including the use of PPAR agonists $(7,114)$, AMPK agonists [metformin (180), AICAR (166)], and ACC antagonists (62, 108). Genetic aproaches specifically promoting liver FAO are of considerable interest. An improvement in high-fat diet (HFD)-induced liver insulin resistance has been described in rodents, in which, FAO was indirectly enhanced by the reduction of malonyl-CoA levels through the modulation of ACC (146) and MCD (4). More interesting are the results obtained with a direct enhancement of mitochondrial FAO by increasing CPT1A expression in liver. Recent studies (117, 130) overexpressing an active and malonyl-CoA-insensitive mutant form of CPT1A (CPT1AM) (118) in obese rodents show that permanently enhanced liver FAO not only rescues impaired hepatic, muscle, and WAT insulin signaling in these animals, but also reduces steatosis, inflammation, and adiposity (Fig. 3). Furthermore, in these studies, enhanced

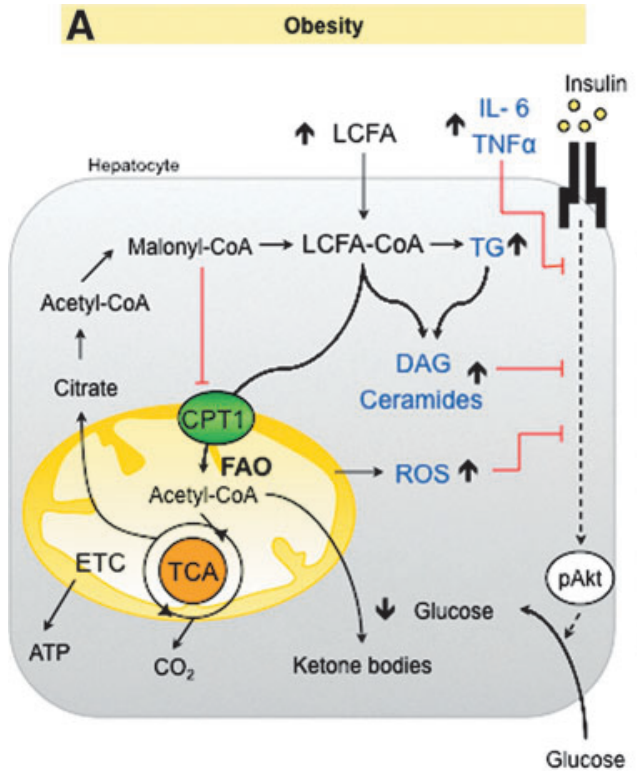

B

Increased FAO in obesity

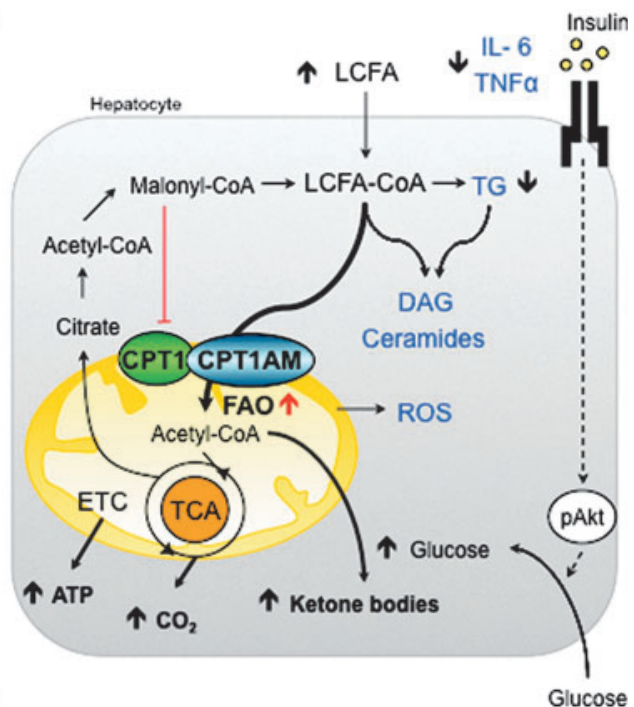

FIG. 3. Effects of enhanced FAO in fatty liver. (A) Obesity increases FA uptake, triglyceride (TG), diacylglycerol (DAG), ceramides, and other lipid derivatives that may inhibit insulin signaling. FA accumulation induces mitochondrial dysfunction and increased ROS production, oxidative stress, and inflammation that could also disrupt insulin signaling. (B) Enhancing FAO by the overexpression of CPT1AM (117, 130) increases the production of ketone bodies, ATP, and $\mathrm{CO}_{2}$. The reduction of lipid content re-establishes lipid metabolism, insulin signaling, and decreases inflammation and ROS production. 
mitochondrial FAO did not increase ROS derivatives or liver injury. Taken together, these results highlight an increase of CPT1A as a new strategy for the treatment of NAFLD/NASH pathologies. Alternatively, it has been reported that the admistration of CPT1 inhibitors reduces gluconeogenesis and improves glucose homeostasis, although chronic treatments on HFD-treated mice caused hepatic steatosis $(28,53)$. This side effect has interrupted the development of other systemic inhibitors, such as etomoxir and 2-tetradecylglycidic acid, as a therapeutic tool. Taken together, these data support the idea that any strategy able to switch liver FA's fate from esterification toward oxidation produces a beneficial effect on the liver and on the whole body. It seems that the liver can deal with an increased flux of FA into the mitochondria, thus escaping from liver injury. This is due to the ability of liver to flip the balance from complete oxidation to ketone body production (88). The ketone bodies produced by enhanced FAO are easily consumed by other tissues, increasing the flux of carbons from liver to other organs. Recently, a new hepatic factor, fibroblast growth factor 21 (FGF21), has emerged as a key regulator in FAO and ketogenic activation. FGF21 is induced in the liver during fasting (136) and has been increasingly pointed to as a potential therapeutic agent in obesity-induced insulin-resistant states (78).

\section{WAT Meets Inflammation and Metabolic Disorders in Obesity}

WAT has long been recognized as the main storage site for lipids derived from food intake (142). This long-term energy reservoir stores lipids mainly in the form of TGs, which can be mobilized and used to generate ATP through the mitochondrial $\beta$-oxidation pathway in peripheral organs during periods of caloric need.

WAT is composed mainly by adipocytes, but also by immune cells, such as macrophages, T cells, and mast cells (68, 104). Thus, WAT is an active and endocrine organ that secretes a large number of adipokines, cytokines, and chemokines (i.e., leptin, adiponectin, resistin, TNF $\alpha$, IL-6, MCP-1, and IL-10), and plays a key role in regulating whole-body glucose and lipid metabolism $(46,151)$.

\section{WAT, obesity, and inflammation}

Obesity is characterized by the expansion of WAT mass due to an increase in both adipocyte number (hyperplasia) and size (hypertrophy), and it is closely associated with insulin resistance in peripheral tissues, such as SkM and liver. In fact, under excess caloric intake, WAT reaches its upper limit for further lipid storage $(157,169)$. Consequently, adipocytes exceed their oxygen diffusion limit, thereby promoting hypoxia (73), ER stress (132), and cell death, and increased circulating FFA and TG accumulation in ectopic sites is produced (145). The combination of microhypoxia and lipid overload triggers the recruitment of immune cells, such as macrophages in the adipose tissue and their activation (103, $129,171)$. Obese adipocytes and infiltrated immune cells secrete a large amount of inflammatory mediators that promote a proinflammatory state through the activation of IKK $\beta$-NF$\mathrm{K} \beta$ and the JNK-Ap1 signaling pathways (151). The induction of JNK leads to serine phosphorylation of IRS-1 and 2, crucial molecules in insulin signaling, and consequently inhibits insulin action. These events cause insulin resistance in adipocytes, exacerbation of the inflammatory state, and systemic insulin resistance $(59,147)$ (Fig. 4).

\section{FFAs, inflammation, and ROS}

Physiological ROS production in adipocytes is a relevant cellular signaling mechanism in the insulin response and it depends mainly on the NADPH oxidase (NOX) family activity (9). In obesity, the excess of FFAs increases NOXmediated ROS generation. Recently, it has been demonstrated that increased ROS in adipocytes exposed to an excess of FFAs does not depend on enhanced mitochondrial flux, but on high levels of TNF $\alpha$ and ER stress as well as the upregulation of aforementioned NOX enzymes $(8,60)$. ROS have the capacity to interfere with insulin signaling, since they activate several downstream pathways involving MAPK, JNK/IKK $\beta$, and
FIG. 4. White adipose tissue (WAT), obesity, and insulin resistance. Nutrient overload, weight gain, and obesity result in increased adipose tissue mass and adipocyte size. The expansion of the adipose tissue leads to adipocyte hypoxia, death, and free fatty acid (FFA) release into circulation. These events trigger the recruitment and activation of immune cells, such as macrophages and $\mathrm{T}$ cells, in the adipose tissue. Infiltrated and activated immune cells and adipocytes secrete large amounts of proinflammatory cytokines, which promote the inhibition of insulin signaling with an ensuing local and systemic resistance (147).

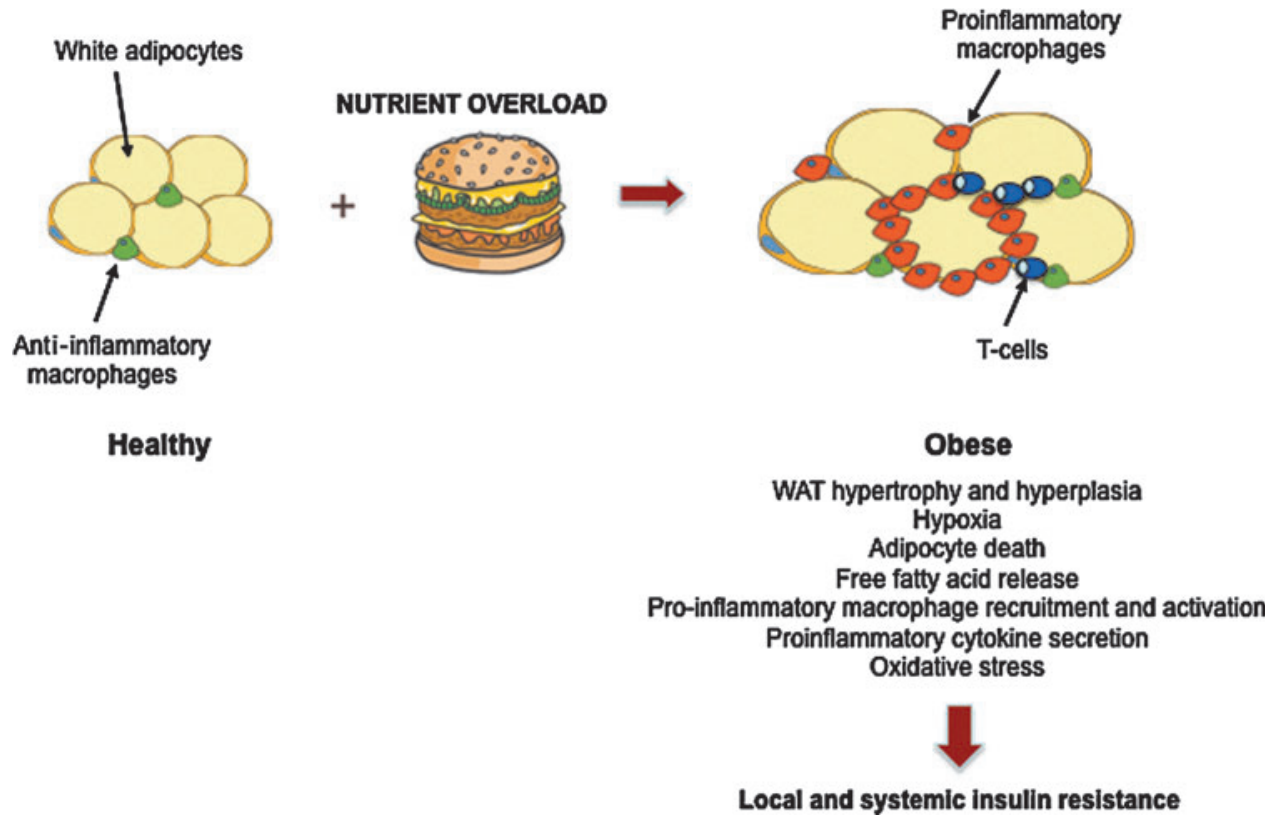


JAK/STAT, which are key contributors to the development of insulin resistance in obesity and type 2 diabetes $(8,75)$.

\section{Enhanced FAO and improvement in insulin sensitivity}

The imbalance between lipid storage and lipid utilization predisposes to adipocyte dysfunction and FFAs promote the proinflammatory response and ROS production involved in severe metabolic disorders. Although the exact physiological role of FAO in WAT remains to be determined, recent studies have shown beneficial effects of increased FAO and lipolysis in adipocytes, through direct CPT1A overexpression. In fact, this rise in lipid utilization improves insulin sensitivity in these cells and suppresses inflammatory signaling (50). However, there is still no evidence that increasing adipose tissue FAO would decrease FFA-induced ROS production. Thus, further research is required to elucidate these mechanisms and to evaluate the potential benefit of this strategy to prevent or reverse obesity and related metabolic diseases.

\section{BAT, Turning Up the Heat}

\section{$B A T$ morphology and function}

In addition to energy-storing WAT, human fat consists of thermogenic controlling BAT. The latter has traditionally received less attention than WAT since it is less abundant and was considered exclusive to rodents and children. However, more recently, BAT have gained relevance in the mechanisms involved in obesity-related disorders.

BAT thermogenesis takes place in its numerous, densely packed mitochondria, which contain the BAT-specific UCP1. Activation of this protein uncouples aerobic respiration by producing heat instead of ATP (162). Brown adipocytes are also differentiated from white adipocytes because of their high expression of type 2 iodothyronnine deiodinase (DIO2), the transcription coregulators, PRDM16 and PGC- $1 \alpha$, and the lipolytic regulator, Cidea $(52,131)$. In rodents, BAT generates heat mainly for two reasons; namely, to protect against cold exposure via nonshivering thermogenesis and to burn the excess calories and reduce fat accumulation $(54,72)$. Therefore, BAT plays a crucial role in protecting mice from dietinduced obesity.

\section{Rediscovery of human BAT}

The fusion of positron emission tomography (PET) and computed tomography $(\mathrm{CT})$ images allowed radiologists to see both functional and structural information in a single image. In the course of using PET-CT to detect and stage tumors in humans, active BAT was observed to increase after cold exposure (124).

However, the real breakthrough arrived in 2009 when five independent groups used PET-CT to identify the presence and study the relevance of BAT in adult humans $(30,143,165$, $168,181)$. All the groups showed major depots of metabolically active fat in the cervical-supraclavicular region, a slightly different site from that in rodents and children, where BAT is found mainly situated in the interscapular area. The expression of UCP1, DIO2, and the $\beta 3$-adrenergic receptor was also reported, thereby indicating the potential responsiveness of human BAT to both hormonal and pharmacological stimuli.
Interestingly, human studies showed that BAT is reduced in obese and diabetic patients, thus indicating that this tissue participates in both cold-induced and diet-induced thermogenesis (30). These observations made BAT a major breakthrough, since any strategy able to increase the mass or activity of this tissue could potentially provide hope for obese and diabetic patients.

\section{BAT bioenergetics and mitochondrial metabolism}

BAT is the only tissue to express UCP1, a protein found in the inner mitochondrial membrane that orchestrates the uncoupled reaction of allowing protons to re-enter the mitochondrial matrix without generating ATP. The dissipation of energy as heat confers BAT with the capacity to control thermogenesis. In fact, altered UCP1 expression (UCP1deficient or transgenic mice) leads to dysregulated sensitivity to cold exposure and body weight control $(40,42,86,87,98)$.

Body temperature changes stimulate norepinephrine release by sympathetic nervous endings that activate $\beta$ adrenergic receptors and trigger a signal transduction cascade that converts nutrients into acetyl-CoA. The TCA cycle uses this mitochondrial fuel to produce protons and electrons, which generate ATP through the ETC. However, in BAT, UCP1 allows protons to enter the mitochondrial matrix without generating ATP, that is, uncoupled, and heat is produced in this process. Thus, BAT burning power intensely clears and oxidizes circulating lipids and glucose to generate heat (17). This observation thus highlights BAT thermogenesis as an attractive therapeutic anti-obesity target.

\section{Enhancing BAT burning power and browning of WAT as an anti-obesity strategy}

Recent landmark studies have identified novel secreted proteins, such as liver FGF21 (72), cardiac natriuretic peptides (11), and irisin (12), that stimulate brown adipocyte thermogenesis. Interestingly, a moderate increase (threefold) in irisin blood levels in mice enhanced energy expenditure and improved obesity and glucose homeostasis (12). In addition, recent articles reported that macrophages (125) and the bone morphogenetic protein BMP8B (172) have also the capacity to regulate BAT thermogenesis. Therefore, promoting BAT activation and/or brown adipocyte recruitment in white fat (browning) are approaches of considerable interest by which to develop pharmacological strategies to improve systemic metabolism by increasing energy expenditure (Fig. 5).

\section{Role of FAO in Muscle Insulin Sensitivity During Obesity}

$\mathrm{SkM}$ is vital for the maintenance of glucose homeostasis. It accounts for $\sim 80 \%$ of total glucose uptake after insulin stimulation (34) and its transition to an insulin-resistant state is central for the pathogenesis of type 2 diabetes (152). Various pathways trigger obesity-induced insulin resistance (147). Both the action of fat-derived cytokines (adipocytokines) and ectopic accumulation of lipid deposition impair SkM function and play a critical role in insulin sensitivity. Obesity is characterized by a greater breakdown and uptake of FAs. Parallel with the increase in circulating lipids, the intramyocellular (IMC) lipid content appears to increase proportionally in obese humans (105) and rodents (23). The lipotoxic hypothesis proposes that FAs and their metabolites (such as DAG and 
FIG. 5. Stimulation of brown adipose tissue (BAT) thermogenesis. Cold exposure, exercise, and some secreted proteins, such as fibroblast growth factor-21 (FGF-21) (72) and irisin (12), enhance BAT burning power by promoting brown adipocyte recruitment in white fat (browning).

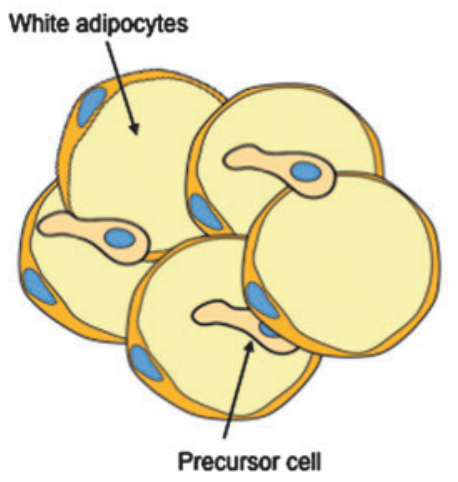

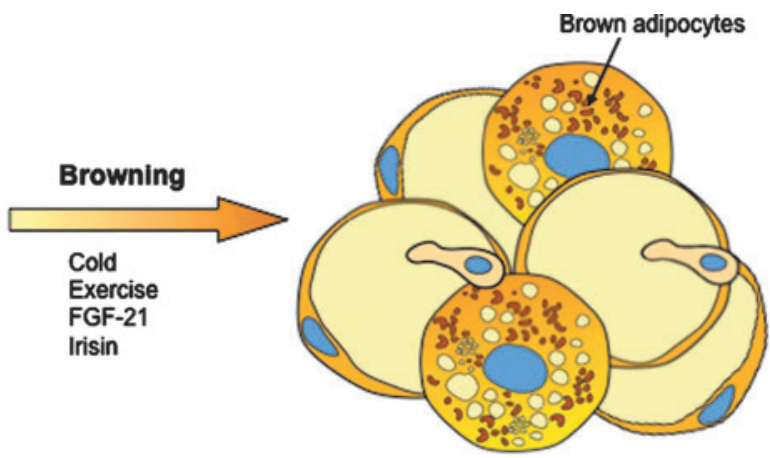

ceramides) are important contributors to lipid-induced insulin resistance in SkM. These molecules activate proinflammatory and nutrient-sensing pathways that lead to the impairment of insulin action (Fig. 6A) [for further information, readers are referred to additional reviews $(144,159)]$.

\section{Muscle FAO in obesity: two sides of the same coin}

Several strategies have been designed to prevent IMC lipid accumulation and its deleterious effects. In SkM, these are mainly focused on the inhibition of FA uptake and esterification and/or the increase in FAO. However, whether the metabolic shift toward fat oxidation ameliorates lipidinduced SkM dysfunction is still open to debate.

Different laboratories have demonstrated that a decrease in the size and number of mitochondria, the activity of proteins in the ETC and, in general, impaired oxidative capacity in SkM are associated with obesity and insulin resistance in humans and animals $(102,139,153)$. Given these observations, it is postulated that increased mitochondrial FAO could prevent lipid accumulation and, thus, improve insulin sensitivity in SkM (Fig. 6B). Several lines of evidence support this idea: (i) exercise in obese humans increases muscle mitochondrial FAO and improves glucose tolerance and insulin sensitivity (16). This effect is probably due to increased CPT1 expression and activity during exercise (163); (ii) direct CPT1 overexpression in animals and SkM cells protects muscle from FA-induced insulin resistance and apoptosis $(15,66,149)$; and (iii) indirect SkM CPT1 activation, by the use of AMPK activators (77) or the ACC2 knockout (1), ameliorates insulinstimulated glucose uptake in rodents.

Despite all the above points, the idea of mitochondrial deficiency as the main cause of diet-induced insulin resistance has been challenged in recent years. First, it is known that SkM's capacity to oxidize substrates is far in excess of what is needed to supply the energy demands of resting muscle (5). With this in mind, it seems clear that the mild $(\approx 30 \%)$ reduction in mitochondrial content observed in obese patients does not affect the ability of resting muscle to oxidize fat. Further, despite the reduction in the mitochondrial content, insulin-resistant SkM has normal mitochondrial function (13). Secondly, since FA and glucose compete as metabolic substrates, the decrease in FAO would produce enhanced glucose utilization instead of insulin resistance. In fact, patients with severe mitochondrial deficiency have an increase in glucose uptake despite the large accumulation of IMC lipids (61). And finally, a HFD causes insulin resistance in rodents, while inducing an increase in SkM mitochondrial biogenesis and $\beta$ - oxidation (164). This suggests that FAO might already be enhanced during obesity, contributing to the development of insulin resistance (121).

The main problems associated with an increase in FAO are: (i) the high rates of incomplete fat oxidation and (ii) the increase in oxidative stress associated with a mitochondrial overload (Fig. 6C) (89). Koves et al. (89) postulated that HFD induces the expression of FAO-related genes, but not those associated with the ETC and TCA cycle. This causes a mismatch between FAO and TCA cycle activity, thus leading to the accumulation of incomplete FAs and other intermediates (i.e., acylcarnitines) that correlate negatively with glucose tolerance (2). How these intermediates mediate the onset of insulin resistance is still unknown. However, studies linking overnutrition with the acylation of mitochondrial proteins are relevant to this topic and suggest a role for acylcarnitines (70). Mitochondrial members of the sirtuin family are known to deacetylate/activate several proteins involved in fat oxidation. This along with the observation that SIRT3 knockout mice have high acylcarnitines and increased acylated mitochondrial proteins and develop metabolic syndrome, implies that mitochondrial accumulation of FAO intermediates triggers metabolic complications via protein modification $(71,80)$.

\section{Role of ROS in muscle insulin signaling}

FAO intermediates may also create an unfavorable environment in the mitochondria, which contributes to the formation of ROS and the development of oxidative stress (119, 120). High levels of ROS and systemic oxidative stress have been associated with obesity and insulin resistance (45). However, these molecules are produced normally during mitochondrial respiration and are essential signal transducers that regulate several cell processes in SkM (8), including the insulin pathway $(64,65)$. Due to its dual role in insulin sensitivity, modulation of redox balance is crucial for correct cell function. On the one hand, under physiological conditions, ROS are generated in response to insulin and are required for its action (69), since the activity of different enzymes that participate in the insulin cascade are dependent on their oxidation state. In particular, the phosphatases that negatively modulate the insulin pathway are the main targets for oxidative inhibition by ROS (35). It has also been reported that ROS enhance insulin sensitivity in HFD mice (100). These molecules are also crucial for the SkM remodeling that occurs in response to exercise (31). ROS show insulin-like effects, stimulating SkM glucose uptake during muscle contraction via the activation of AMPK (81) and the induction of PGC- $1 \alpha$ 


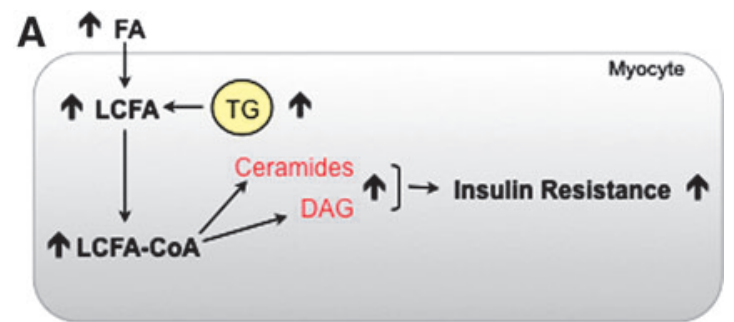

B
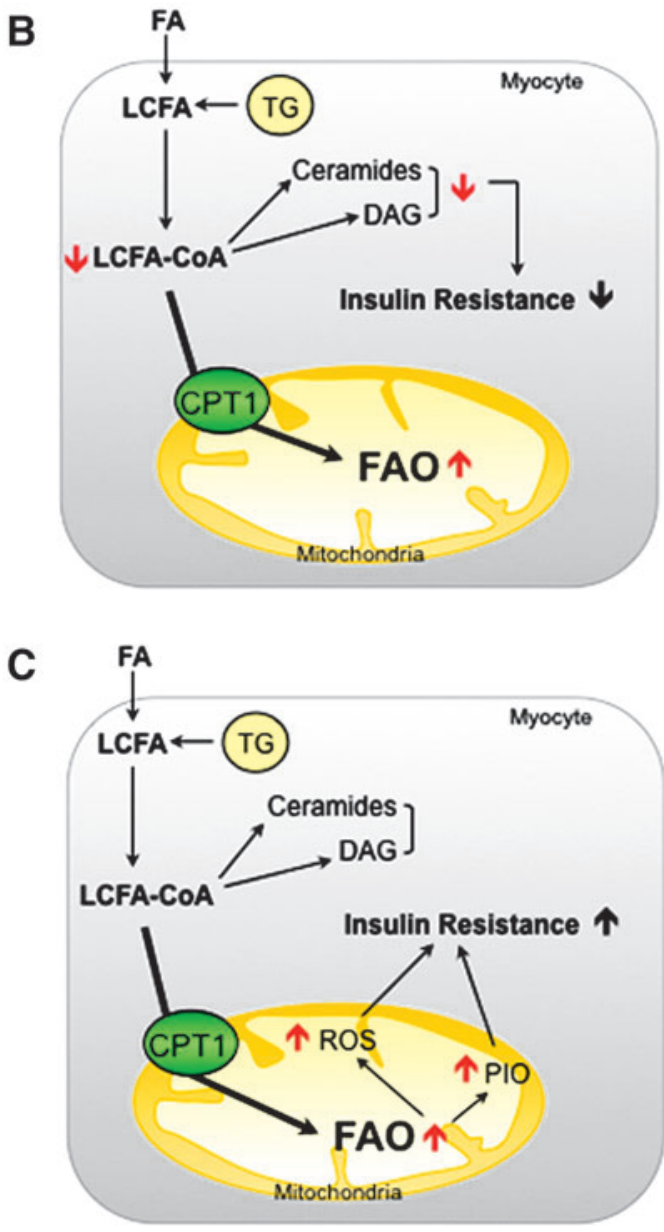

FIG. 6. Two hypotheses for the role of FAO in the development of obese-induced insulin resistance in skeletal muscle (SkM). (A) During obesity, intramyocellular lipid accumulation leads to a decrease in insulin-stimulated glucose uptake in SkM (144). (B) An increase in FAO may decrease LCFAs, ceramide, and DAG content, thus enhancing insulin action $(15,66,149)$. (C) However, an increase in FAO may augment ROS production and enhance the accumulation of products of incomplete $\beta$-oxidation (PIO), which are hypothesized to decrease insulin signaling through the activation of various stress kinases (89).

expression in vitro and in vivo $(57,79)$. On the other hand, during a pathophysiological state, abundant evidence indicates that a large and sustained increase in ROS impairs insulin action, through the activation of stress signaling pathways (i.e., MAPK and JNK) $(85,154)$, contributing to the pathogenesis of diet-induced insulin resistance (67). Therefore, clarifying the role of mitochondrial FAO, and the ROS production derived from it, in diet-induced SkM insulin-resistance is crucial to the development of new therapeutic strategies to fight against obesity and its related metabolic complications.

\section{Hypothalamic FAO in the Regulation of Food Intake}

Excess food intake in obesity is related to behavioral processes controlled by the central nervous system. Specific hypothalamic nuclei, which sense nutrients and modify energy intake and expenditure to maintain a balance, are responsible for regulating this intake (48). The mechanisms for sensing the nutritional state have not been fully discovered and less is known about lipid than glucose sensing. Nonetheless, there are two classic hypotheses on nutritional state metabolic mediators, involving malonyl-CoA and LCFA-CoA.

\section{CPT1A on food intake control: linking the malonyl-CoA and LCFA-COA hypotheses}

Strong evidence shows that increased malonyl-CoA levels, which are generated by activated (i.e., dephosphorylated) ACC, act as abundance indicators, thereby diminishing food intake and consequently body weight (173). During starvation, ACC phosphorylation is mainly controlled by the wellknown energy sensor, AMPK (115), which acts also as an important hub, integrating in-cell energetic state sensing and its modulation due to different circulating hormones. Concretely, ghrelin-mediated activation (i.e., phosphorylation) of AMPK is done via SIRT1-mediated activation (i.e., deacetylation) of p53. It is known that the SIRT1 activity is increased in hypothalamus during starvation with high ghrelin levels (167). The mechanism of leptin action also appears to be related to increases in physiological malonyl-CoA in the arcuate nucleus, which promotes a reduction in food intake and body weight, using different mechanisms to those previously reported for ghrelin action, during energetically wealthy states $(49,141)$.

In addition, LCFA-CoA levels have also been put forward as mediators in nutritional state sensing. During starvation, circulating FFA increase can be sensed in hypothalamic nuclei through in-cell activation to LCFA-CoA. This increase, previous to active ghrelin rise, is an early reporter of a deficient nutritional state (156). However, unfortunately, no cytoplasmic LCFA-CoA increase in hypothalamus has been found. Even so, in the last decade, pharmacological and genetic inhibition of hypothalamic CPT1A has been reported to reduce the food intake $(10,110,127)$, potentially as a result of LCFACoA cytoplasmic accumulation. Furthermore, the role of malonyl-CoA as a CPT1 inhibitor is worth noting, to link the two hypotheses.

Regardless of whether malonyl-CoA or LCFA-CoA is the main actor, changes in feeding behavior and peripheral metabolism are conducted via the action of neuropeptides, such as agouti-related protein (AgRP), neuropeptide Y (NPY), and melanocortins. Transcription factors affected by changes in hypothalamic FAO, such as CREB, FoxO1, and BSX, are involved in ghrelin-induced expression of NPY and AgRP (92). However, it is still unknown whether high levels of LCFA-CoA trigger NPY and AgRP via BSX and subsequent transcription factors. Probably, neither malonyl-CoA nor LCFACoA act as key molecular mediators per se to induce the expression of the different food intake-controller neuropeptides, 
but they are just two of the several pieces involved in the highly complex hypothalamic nutritional state sensing system, which is still not fully understood.

The relevance of FAO in neuronal cells is controversial because glucose is the brain's primary energy source. However, basal levels of FAO enzymes and FA transport proteins (such as FATP-1, FATP-4, and FAT/CD36) are expressed in hypothalamic neurons $(93,95)$. Additionally, the presence of such small, but functional FAO could be explained by its essential role in neuronal FA turnover and its action as a lipidsensing mediator for energy homeostasis (113). There is also another controversy regarding fasting, because during fasting, high blood FFA levels presumably reach hypothalamic nuclei. This does not fit in with the satiety effect observed in early experiments with high LCFA concentration in the hypothalamus (128). Nonetheless, the direct correlation observed between fasting and FFA levels (156) and the capacity of hypothalamic neurons to sense glucose and FFA simultaneously and to integrate other nutritional and hormonal inputs $(95,99)$ seem to throw light on how important FAO really is in hypothalamic nuclei.

\section{ROS, third in discord}

Along with malonyl-CoA and LCFA-CoA, mitochondrial ROS have been put forward as a mediator in response to nutrient availability (140) (Fig. 7). ROS in the hypothalamus are produced chiefly in mitochondria ECT complexes. Concretely, some authors pointed to complex I as the most relevant site for single electron reduction in brain mitochondria (90). Various kinases and transcription factors, involved in neuropeptide regulation, have been reported to be modulated by redox signaling $(33,91)$. Further, the signaling under different levels of ROS may imply dissimilar pathophysiological changes in proteins, depending on their redox state (33). A

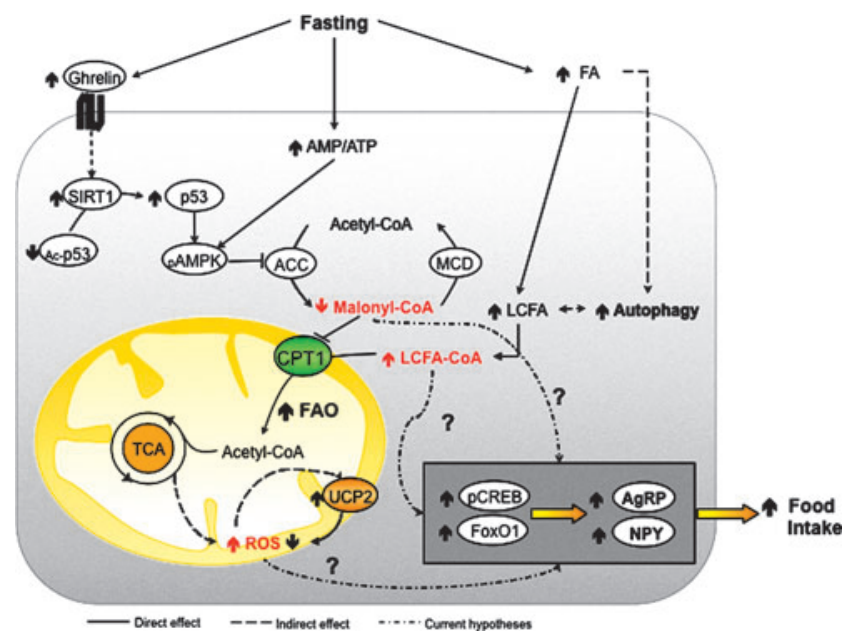

FIG. 7. Hypotheses involving FAO in the regulation of food intake. During fasting, the effects of ghrelin, AMP, and FAs act in hypothalamic nuclei to increase the expression of orexigenic neuropeptides (48). The mechanisms involved in this process appear to be related to an increase in LCFACoA, diminished malonyl-CoA, and a certain level of ROS. Excessive ROS production is controlled by UCP2 with a negative feed-back. CPT1A is postulated to be involved in all the three approaches. certain level of ROS, without being excessive, is probably required to trigger neuropeptide expression. This notion may explain the importance of UCP2 as a ROS scavenger to keep a physiological ROS level that allows correct NPY and AgRP expression in the hypothalamus (6). In addition to all these considerations, the recent finding that hypothalamic autophagy is a source of endogenous FFA to regulate AgRP levels (82) could be explained by increased mitochondrial FAO and ROS signaling. However, further research is needed to establish the contribution of ROS to the hypothalamic control of food intake.

\section{Innovation}

Recent results suggest that enhancing cellular energy expenditure may be an attractive therapy to prevent or reverse the exponential growth of obesity-related disorders. We reviewed those recent discoveries regarding mitochondrial FAO and its potential as a therapy for obesity.

\section{Conclusions}

Despite considerable current efforts, the prevalence of obesity and associated diseases is rising exponentially in both industrialized and developing countries worldwide. This is especially worrying in the young. Current therapeutic strategies, focused mainly on controlling food intake, have met limited success, probably due to the inherent resistance of the human body to weight loss. However, recent approaches targeting energy expenditure and mitochondrial FAO shed light on new therapies to fight obesity.

Mitochondrial FAO is the cell source of energy from FAs. Since an excess of lipids is found in obesity and associated pathologies, a lot of research studies how to eliminate them through an increase in FAO. Beneficial effects of an increase in energy expenditure in obesity have been described in several tissues, including liver, muscle, WAT, and BAT. On the contrary, FAO therapeutic inhibition in hypothalamus seems to reduce food intake. Whether or not FAO should be modulated in the above-mentioned tissues to improve insulin resistance or to lose weight is still a subject of debate. There is no doubt regarding the involvement of ROS in pathophysiological processes related to obesity, and CPT1 seems to be a good molecular target for ROS and FAO modulation. However, several questions still need to be answered before FAO can become an obesity therapy. First, it is not known whether a long-term increase in energy expenditure would cause an enhancement of appetite as a compensatory mechanism. Second, an increase in FAO could induce pathological levels of ROS and/or other incomplete oxidation products. Third, it is not known whether FAO enhancement might reach a limit in a specific tissue, such as in BAT, in which thermogenesis is tightly adjusted to the environmental temperature. Finally, since increasing flux through $\beta$-oxidation would only make sense together with a corresponding enhancement in energy demand (121), the physiological relevance of improved mitochondrial FAO might be questioned if the individual remains sedentary (muscle, WAT, or liver) or warm (BAT). Potential mechanisms to explain the beneficial effects of targeting mitochondrial FAO could be the concomitant enhancement of hepatic ketone bodies, $\mathrm{CO}_{2}$, acid soluble products, ATP production, and endergonic processes (e.g., gluconeogenesis) seen in previous publications $(38,130,158)$. 
Increased FAO may also decrease glucose oxidation to maintain energy homeostasis, augment mitochondrial burning capacity through an increase in the number of mitochondria and/or the increased expression of UCPs, and thus dissipate the excess of energy as heat and ATP. All of these could well alleviate the mitochondrial pressure found in lipid overload states. Thus, an increase in energy expenditure could indeed be the underlying protective mechanism against obesity-induced metabolic abnormalities.

Although more research is needed, we are encouraged that targeting of FAO and cell energy expenditure may be available in the near future as therapies to treat obesity and its associated severe diseases.

\section{Acknowledgments}

We thank Professor Fausto G. Hegardt for helpful, inspiring, and wise discussions and the Language Service of the University of Barcelona for valuable assistance in the preparation of the English manuscript. This study was supported by the Spanish Ministry of Science and Innovation (Grant SAF2010-20039 to L.H., Grant SAF2011-30520-C02-01 to D.S., and doctoral fellowships to M.I.M. and J.F.M.), by the CIBER Fisiopatología de la Obesidad y la Nutrición (CIBEROBN), Instituto de Salud Carlos III (Grant CB06/03/0026 to D.S. and research contract to P.M.), and by the EFSD/Lilly and EFSD/ Janssen (research fellowships to L.H.).

\section{References}

1. Abu-Elheiga L, Oh W, Kordari P, and Wakil SJ. Acetyl-CoA carboxylase 2 mutant mice are protected against obesity and diabetes induced by high-fat/high-carbohydrate diets. Proc Natl Acad Sci U S A 100: 10207-10212, 2003.

2. Adams SH, Hoppel CL, Lok KH, Zhao L, Wong SW, Minkler PE, Hwang DH, Newman JW, and Garvey WT. Plasma acylcarnitine profiles suggest incomplete longchain fatty acid beta-oxidation and altered tricarboxylic acid cycle activity in type 2 diabetic African-American women. J Nutr 139: 1073-1081, 2009.

3. Ahima RS. Digging deeper into obesity. J Clin Invest 121: 2076-2079, 2011.

4. An J, Muoio DM, Shiota M, Fujimoto Y, Cline GW, Shulman GI, Koves TR, Stevens R, Millington D, and Newgard CB. Hepatic expression of malonyl-CoA decarboxylase reverses muscle, liver and whole-animal insulin resistance. Nat Med 10: 268-274, 2004.

5. Andersen P and Saltin B. Maximal perfusion of skeletal muscle in man. J Physiol 366: 233-249, 1985.

6. Andrews ZB, Liu ZW, Walllingford N, Erion DM, Borok E, Friedman JM, Tschop MH, Shanabrough M, Cline G, Shulman GI, Coppola A, Gao XB, Horvath TL, and Diano S. UCP2 mediates ghrelin's action on NPY/AgRP neurons by lowering free radicals. Nature 454: 846-851, 2008.

7. Barroso E, Rodriguez-Calvo R, Serrano-Marco L, Astudillo AM, Balsinde J, Palomer X, and Vazquez-Carrera M. The PPARbeta/delta activator GW501516 prevents the downregulation of AMPK caused by a high-fat diet in liver and amplifies the PGC-1alpha-Lipin 1-PPARalpha pathway leading to increased fatty acid oxidation. Endocrinology 152: 1848-1859, 2011.

8. Bashan N, Kovsan J, Kachko I, Ovadia H, and Rudich A. Positive and negative regulation of insulin signaling by reactive oxygen and nitrogen species. Physiol Rev 89: 27-71, 2009.
9. Bedard $\mathrm{K}$ and Krause KH. The NOX family of ROSgenerating NADPH oxidases: physiology and pathophysiology. Physiol Rev 87: 245-313, 2007.

10. Bentebibel A, Sebastian D, Herrero L, Lopez-Vinas E, Serra D, Asins G, Gomez-Puertas P, and Hegardt FG. Novel effect of C75 on carnitine palmitoyltransferase I activity and palmitate oxidation. Biochemistry 45: 4339-4350, 2006.

11. Bordicchia M, Liu D, Amri EZ, Ailhaud G, Dessi-Fulgheri P, Zhang C, Takahashi N, Sarzani R, and Collins S. Cardiac natriuretic peptides act via $\mathrm{p} 38$ MAPK to induce the brown fat thermogenic program in mouse and human adipocytes. J Clin Invest 122: 1022-1036, 2012.

12. Bostrom P, Wu J, Jedrychowski MP, Korde A, Ye L, Lo JC, Rasbach KA, Bostrom EA, Choi JH, Long JZ, Kajimura S, Zingaretti MC, Vind BF, Tu H, Cinti S, Hojlund K, Gygi SP, and Spiegelman BM. A PGC1-alpha-dependent myokine that drives brown-fat-like development of white fat and thermogenesis. Nature 481: 463-468, 2012.

13. Boushel R, Gnaiger E, Schjerling P, Skovbro M, Kraunsoe R, and Dela F. Patients with type 2 diabetes have normal mitochondrial function in skeletal muscle. Diabetologia 50: 790-796, 2007.

14. Brady LJ, Brady PS, Romsos DR, and Hoppel CL. Elevated hepatic mitochondrial and peroxisomal oxidative capacities in fed and starved adult obese (ob/ob) mice. Biochem J 231: 439-444, 1985.

15. Bruce CR, Hoy AJ, Turner N, Watt MJ, Allen TL, Carpenter K, Cooney GJ, Febbraio MA, and Kraegen EW. Overexpression of carnitine palmitoyltransferase- 1 in skeletal muscle is sufficient to enhance fatty acid oxidation and improve high-fat diet-induced insulin resistance. Diabetes 58: 550-558, 2009.

16. Bruce CR, Thrush AB, Mertz VA, Bezaire V, Chabowski A, Heigenhauser GJ, and Dyck DJ. Endurance training in obese humans improves glucose tolerance and mitochondrial fatty acid oxidation and alters muscle lipid content. Am J Physiol Endocrinol Metab 291: E99-E107, 2006.

17. Cannon B and Nedergaard J. Brown adipose tissue: function and physiological significance. Physiol Rev 84: 277-359, 2004.

18. Canto C, Gerhart-Hines Z, Feige JN, Lagouge M, Noriega L, Milne JC, Elliott PJ, Puigserver P, and Auwerx J. AMPK regulates energy expenditure by modulating NAD + metabolism and SIRT1 activity. Nature 458: 1056-1060, 2009.

19. Chakravarthy MV, Lodhi IJ, Yin L, Malapaka RR, Xu HE, Turk J, and Semenkovich CF. Identification of a physiologically relevant endogenous ligand for PPARalpha in liver. Cell 138: 476-488, 2009.

20. Chakravarthy MV, Pan Z, Zhu Y, Tordjman K, Schneider JG, Coleman T, Turk J, and Semenkovich CF. "New" hepatic fat activates PPARalpha to maintain glucose, lipid, and cholesterol homeostasis. Cell Metab 1: 309-322, 2005.

21. Chance B, Sies H, and Boveris A. Hydroperoxide metabolism in mammalian organs. Physiol Rev 59: 527-605, 1979.

22. Chatelain F, Kohl C, Esser V, McGarry JD, Girard J, and Pegorier JP. Cyclic AMP and fatty acids increase carnitine palmitoyltransferase I gene transcription in cultured fetal rat hepatocytes. Eur J Biochem 235: 789-798, 1996.

23. Chen MT, Kaufman LN, Spennetta T, and Shrago E. Effects of high fat-feeding to rats on the interrelationship of body weight, plasma insulin, and fatty acyl-coenzyme A esters in liver and skeletal muscle. Metabolism 41: 564-569, 1992.

24. Choi CS, Savage DB, Abu-Elheiga L, Liu ZX, Kim S, Kulkarni A, Distefano A, Hwang YJ, Reznick RM, Codella R, Zhang D, Cline GW, Wakil SJ, and Shulman GI. Con- 
tinuous fat oxidation in acetyl-CoA carboxylase 2 knockout mice increases total energy expenditure, reduces fat mass, and improves insulin sensitivity. Proc Natl Acad Sci U S A 104: 16480-16485, 2007.

25. Ciapaite J, van den Broek NM, Te Brinke H, Nicolay K, Jeneson JA, Houten SM, and Prompers JJ. Differential effects of short- and long-term high-fat diet feeding on hepatic fatty acid metabolism in rats. Biochim Biophys Acta 1811: 441-451, 2011.

26. Cnop M, Foufelle F, and Velloso LA. Endoplasmic reticulum stress, obesity and diabetes. Trends Mol Med 18: 59-68, 2012.

27. Cohen JC, Horton JD, and Hobbs HH. Human fatty liver disease: old questions and new insights. Science 332: 1519$1523,2011$.

28. Conti R, Mannucci E, Pessotto P, Tassoni E, Carminati P, Giannessi F, and Arduini A. Selective reversible inhibition of liver carnitine palmitoyl-transferase 1 by teglicar reduces gluconeogenesis and improves glucose homeostasis. Diabetes 60: 644-651, 2011.

29. Cook GA and Gamble MS. Regulation of carnitine palmitoyltransferase by insulin results in decreased activity and decreased apparent Ki values for malonyl-CoA. J Biol Chem 262: 2050-2055, 1987.

30. Cypess AM, Lehman S, Williams G, Tal I, Rodman D, Goldfine AB, Kuo FC, Palmer EL, Tseng YH, Doria A, Kolodny GM, and Kahn CR. Identification and importance of brown adipose tissue in adult humans. $N$ Engl J Med 360: 1509-1517, 2009.

31. Davies KJ, Quintanilha AT, Brooks GA, and Packer L. Free radicals and tissue damage produced by exercise. Biochem Biophys Res Commun 107: 1198-1205, 1982.

32. Day CP and James OF. Steatohepatitis: a tale of two "hits"? Gastroenterology 114: 842-845, 1998.

33. de Keizer PL, Burgering BM, and Dansen TB. Forkhead box $\mathrm{o}$ as a sensor, mediator, and regulator of redox signaling. Antioxid Redox Signal 14: 1093-1106, 2010.

34. DeFronzo RA, Jacot E, Jequier E, Maeder E, Wahren J, and Felber JP. The effect of insulin on the disposal of intravenous glucose. Results from indirect calorimetry and hepatic and femoral venous catheterization. Diabetes 30: 1000-1007, 1981.

35. Denu JM and Tanner KG. Redox regulation of protein tyrosine phosphatases by hydrogen peroxide: detecting sulfenic acid intermediates and examining reversible inactivation. Methods Enzymol 348: 297-305, 2002.

36. Derosa G and Maffioli P. Anti-obesity drugs: a review about their effects and their safety. Expert Opin Drug Saf 11: 459-471, 2012.

37. Donnelly KL, Smith CI, Schwarzenberg SJ, Jessurun J, Boldt $\mathrm{MD}$, and Parks EJ. Sources of fatty acids stored in liver and secreted via lipoproteins in patients with nonalcoholic fatty liver disease. J Clin Invest 115: 1343-1351, 2005.

38. Drynan L, Quant PA, and Zammit VA. Flux control exerted by mitochondrial outer membrane carnitine palmitoyltransferase over beta-oxidation, ketogenesis and tricarboxylic acid cycle activity in hepatocytes isolated from rats in different metabolic states. Biochem J 317: 791-795, 1996.

39. Dyck JR, Berthiaume LG, Thomas PD, Kantor PF, Barr AJ, Barr R, Singh D, Hopkins TA, Voilley N, Prentki M, and Lopaschuk GD. Characterization of rat liver malonyl-CoA decarboxylase and the study of its role in regulating fatty acid metabolism. Biochem J 350: 599-608, 2000.

40. Enerback S, Jacobsson A, Simpson EM, Guerra C, Yamashita H, Harper ME, and Kozak LP. Mice lacking mito- chondrial uncoupling protein are cold-sensitive but not obese. Nature 387: 90-94, 1997.

41. Esser V, Britton CH, Weis BC, Foster DW, and McGarry JD. Cloning, sequencing, and expression of a cDNA encoding rat liver carnitine palmitoyltransferase I. Direct evidence that a single polypeptide is involved in inhibitor interaction and catalytic function. J Biol Chem 268: 5817-5822, 1993.

42. Feldmann HM, Golozoubova V, Cannon B, and Nedergaard J. UCP1 ablation induces obesity and abolishes diet-induced thermogenesis in mice exempt from thermal stress by living at thermoneutrality. Cell Metab 9: 203-209, 2009.

43. Fromenty B and Pessayre D. Inhibition of mitochondrial beta-oxidation as a mechanism of hepatotoxicity. Pharmacol Ther 67: 101-154, 1995.

44. Fromenty B, Robin MA, Igoudjil A, Mansouri A, and Pessayre D. The ins and outs of mitochondrial dysfunction in NASH. Diabetes Metab 30: 121-138, 2004.

45. Furukawa S, Fujita T, Shimabukuro M, Iwaki M, Yamada Y, Nakajima Y, Nakayama O, Makishima M, Matsuda M, and Shimomura I. Increased oxidative stress in obesity and its impact on metabolic syndrome. J Clin Invest 114: 1752 1761, 2004

46. Galic S, Oakhill JS, and Steinberg GR. Adipose tissue as an endocrine organ. Mol Cell Endocrinol 316: 129-139, 2010.

47. Gambino R, Musso G, and Cassader M. Redox balance in the pathogenesis of nonalcoholic fatty liver disease: mechanisms and therapeutic opportunities. Antioxid Redox Signal 15: 1325-1365, 2011.

48. Gao Q and Horvath TL. Neurobiology of feeding and energy expenditure. Annu Rev Neurosci 30: 367-398, 2007.

49. Gao S, Kinzig KP, Aja S, Scott KA, Keung W, Kelly S, Strynadka K, Chohnan S, Smith WW, Tamashiro KL, Ladenheim EE, Ronnett GV, Tu Y, Birnbaum MJ, Lopaschuk GD, and Moran TH. Leptin activates hypothalamic acetylCoA carboxylase to inhibit food intake. Proc Natl Acad Sci U S A 104: 17358-17363, 2007.

50. Gao X, Li K, Hui X, Kong X, Sweeney G, Wang Y, Xu A, Teng M, Liu P, and Wu D. Carnitine palmitoyltransferase $1 \mathrm{~A}$ prevents fatty acid-induced adipocyte dysfunction through suppression of c-Jun N-terminal kinase. Biochem J 435: 723-732, 2011.

51. Gautron L and Elmquist JK. Sixteen years and counting: an update on leptin in energy balance. J Clin Invest 121: 20872093, 2011.

52. Gesta S, Tseng YH, and Kahn CR. Developmental origin of fat: tracking obesity to its source. Cell 131: 242-256, 2007.

53. Giannessi F, Pessotto P, Tassoni E, Chiodi P, Conti R, De Angelis F, Dell'Uomo N, Catini R, Deias R, Tinti MO, Carminati $\mathrm{P}$, and Arduini A. Discovery of a long-chain carbamoyl aminocarnitine derivative, a reversible carnitine palmitoyltransferase inhibitor with antiketotic and antidiabetic activity. J Med Chem 46: 303-309, 2003.

54. Giralt A, Hondares E, Villena JA, Ribas F, Diaz-Delfin J, Giralt M, Iglesias R, and Villarroya F. Peroxisome proliferator-activated receptor-gamma coactivator-1alpha controls transcription of the Sirt3 gene, an essential component of the thermogenic brown adipocyte phenotype. $J$ Biol Chem 286: 16958-16966, 2011.

55. Goldberg IJ and Ginsberg HN. Ins and outs modulating hepatic triglyceride and development of nonalcoholic fatty liver disease. Gastroenterology 130: 1343-1346, 2006.

56. Goldfine AB, Fonseca V, and Shoelson SE. Therapeutic approaches to target inflammation in type 2 diabetes. Clin Chem 57: 162-167, 2011. 
57. Gomez-Cabrera MC, Domenech E, Romagnoli M, Arduini A, Borras C, Pallardo FV, Sastre J, and Vina J. Oral administration of vitamin $C$ decreases muscle mitochondrial biogenesis and hampers training-induced adaptations in endurance performance. Am J Clin Nutr 87: 142-149, 2008.

58. Gregor MF and Hotamisligil GS. Thematic review series: Adipocyte Biology. Adipocyte stress: the endoplasmic reticulum and metabolic disease. J Lipid Res 48: 1905-1914, 2007.

59. Guilherme A, Virbasius JV, Puri V, and Czech MP. Adipocyte dysfunctions linking obesity to insulin resistance and type 2 diabetes. Nat Rev Mol Cell Biol 9: 367-377, 2008.

60. Han CY, Umemoto T, Omer M, Den Hartigh LJ, Chiba T, Leboeuf R, Buller CL, Sweet IR, Pennathur S, Abel ED, and Chait A. NADPH Oxidase-derived Reactive Oxygen Species Increases Expression of Monocyte Chemotactic Factor Genes in Cultured Adipocytes. J Biol Chem 287: 10379-10393, 2012.

61. Han DH, Nolte LA, Ju JS, Coleman T, Holloszy JO, and Semenkovich CF. UCP-mediated energy depletion in skeletal muscle increases glucose transport despite lipid accumulation and mitochondrial dysfunction. Am J Physiol Endocrinol Metab 286: E347-E353, 2004.

62. Harwood HJ, Jr., Petras SF, Shelly LD, Zaccaro LM, Perry DA, Makowski MR, Hargrove DM, Martin KA, Tracey WR, Chapman JG, Magee WP, Dalvie DK, Soliman VF, Martin WH, Mularski CJ, and Eisenbeis SA. Isozyme-nonselective $\mathrm{N}$-substituted bipiperidylcarboxamide acetyl-CoA carboxylase inhibitors reduce tissue malonyl-CoA concentrations, inhibit fatty acid synthesis, and increase fatty acid oxidation in cultured cells and in experimental animals. J Biol Chem 278: 37099-37111, 2003.

63. Hatori M, Vollmers C, Zarrinpar A, Ditacchio L, Bushong EA, Gill S, Leblanc M, Chaix A, Joens M, Fitzpatrick JA, Ellisman $\mathrm{MH}$, and Panda S. Time-restricted feeding without reducing caloric intake prevents metabolic diseases in mice fed a high-fat diet. Cell Metab 15: 848-860, 2012.

64. Hayes GR and Lockwood DH. Role of insulin receptor phosphorylation in the insulinomimetic effects of hydrogen peroxide. Proc Natl Acad Sci U S A 84: 8115-8119, 1987.

65. Heffetz D, Bushkin I, Dror R, and Zick Y. The insulinomimetic agents $\mathrm{H} 2 \mathrm{O} 2$ and vanadate stimulate protein tyrosine phosphorylation in intact cells. J Biol Chem 265: 2896-2902, 1990.

66. Henique C, Mansouri A, Fumey G, Lenoir V, Girard J, Bouillaud F, Prip-Buus C, and Cohen I. Increased mitochondrial fatty acid oxidation is sufficient to protect skeletal muscle cells from palmitate-induced apoptosis. J Biol Chem 285: 36818-36827, 2010.

67. Henriksen EJ, Diamond-Stanic MK, and Marchionne EM. Oxidative stress and the etiology of insulin resistance and type 2 diabetes. Free Radic Biol Med 51: 993-999, 2011.

68. Herrero L, Shapiro H, Nayer A, Lee J, and Shoelson SE. Inflammation and adipose tissue macrophages in lipodystrophic mice. Proc Natl Acad Sci U S A 107: 240-245, 2010.

69. Higaki Y, Mikami T, Fujii N, Hirshman MF, Koyama K, Seino T, Tanaka K, and Goodyear LJ. Oxidative stress stimulates skeletal muscle glucose uptake through a phosphatidylinositol 3-kinase-dependent pathway. Am J Physiol Endocrinol Metab 294: E889-E897, 2008.

70. Hirschey MD, Shimazu T, Huang JY, and Verdin E. Acetylation of mitochondrial proteins. Methods Enzymol 457: 137-147, 2009.

71. Hirschey MD, Shimazu T, Jing E, Grueter CA, Collins AM, Aouizerat B, Stancakova A, Goetzman E, Lam MM, Schwer B, Stevens RD, Muehlbauer MJ, Kakar S, Bass NM, Kuusisto J, Laakso M, Alt FW, Newgard CB, Farese RV Jr.,
Kahn CR, and Verdin E. SIRT3 deficiency and mitochondrial protein hyperacetylation accelerate the development of the metabolic syndrome. Mol Cell 44: 177-190, 2011.

72. Hondares E, Rosell M, Gonzalez FJ, Giralt M, Iglesias R, and Villarroya F. Hepatic FGF21 expression is induced at birth via PPARalpha in response to milk intake and contributes to thermogenic activation of neonatal brown fat. Cell Metab 11: 206-212, 2010.

73. Hosogai N, Fukuhara A, Oshima K, Miyata Y, Tanaka S, Segawa K, Furukawa S, Tochino Y, Komuro R, Matsuda M, and Shimomura I. Adipose tissue hypoxia in obesity and its impact on adipocytokine dysregulation. Diabetes 56: 901911, 2007.

74. Hotamisligil GS. Endoplasmic reticulum stress and the inflammatory basis of metabolic disease. Cell 140: 900-917, 2010.

75. Houstis N, Rosen ED, and Lander ES. Reactive oxygen species have a causal role in multiple forms of insulin resistance. Nature 440: 944-948, 2006.

76. Huang W, Ramsey KM, Marcheva B, and Bass J. Circadian rhythms, sleep, and metabolism. J Clin Invest 121: 21332141, 2011.

77. Iglesias MA, Ye JM, Frangioudakis G, Saha AK, Tomas E, Ruderman NB, Cooney GJ, and Kraegen EW. AICAR administration causes an apparent enhancement of muscle and liver insulin action in insulin-resistant high-fat-fed rats. Diabetes 51: 2886-2894, 2002.

78. Iglesias P, Selgas R, Romero S, and Diez JJ. Biological role. Clinical significance and therapeutic possibilities of the recently discovered metabolic hormone fibroblastic growth factor 21. Eur J Endocrinol 167: 301-309, 2012.

79. Irrcher I, Ljubicic V, and Hood DA. Interactions between ROS and AMP kinase activity in the regulation of PGC1alpha transcription in skeletal muscle cells. Am J Physiol Cell Physiol 296: C116-C123, 2009.

80. Jing E, Emanuelli B, Hirschey MD, Boucher J, Lee KY, Lombard D, Verdin EM, and Kahn CR. Sirtuin-3 (Sirt3) regulates skeletal muscle metabolism and insulin signaling via altered mitochondrial oxidation and reactive oxygen species production. Proc Natl Acad Sci U S A 108: 1460814613, 2011.

81. Katz A. Modulation of glucose transport in skeletal muscle by reactive oxygen species. J Appl Physiol 102: 1671-1676, 2007.

82. Kaushik S, Rodriguez-Navarro JA, Arias E, Kiffin R, Sahu S, Schwartz GJ, Cuervo AM, and Singh R. Autophagy in hypothalamic AgRP neurons regulates food intake and energy balance. Cell Metab 14: 173-183, 2011.

83. Keller H, Dreyer C, Medin J, Mahfoudi A, Ozato K, and Wahli W. Fatty acids and retinoids control lipid metabolism through activation of peroxisome proliferatoractivated receptor-retinoid $\mathrm{X}$ receptor heterodimers. Proc Natl Acad Sci U S A 90: 2160-2164, 1993.

84. Khan A, Raza S, Khan Y, Aksoy T, Khan M, Weinberger Y, and Goldman J. Current updates in the medical management of obesity. Recent Pat Endocr Metab 6: 117-128, 2012.

85. Kim JS, Saengsirisuwan V, Sloniger JA, Teachey MK, and Henriksen EJ. Oxidant stress and skeletal muscle glucose transport: roles of insulin signaling and p38 MAPK. Free Radic Biol Med 41: 818-824, 2006.

86. Kontani Y, Wang Y, Kimura K, Inokuma KI, Saito M, Suzuki-Miura T, Wang Z, Sato Y, Mori N, and Yamashita H. UCP1 deficiency increases susceptibility to diet-induced obesity with age. Aging Cell 4: 147-155, 2005.

87. Kopecky J, Clarke G, Enerback S, Spiegelman B, and Kozak LP. Expression of the mitochondrial uncoupling protein 
gene from the aP2 gene promoter prevents genetic obesity. J Clin Invest 96: 2914-2923, 1995.

88. Kotronen A, Seppala-Lindroos A, Vehkavaara S, Bergholm R, Frayn KN, Fielding BA, and Yki-Jarvinen H. Liver fat and lipid oxidation in humans. Liver Int 29: 1439-1446, 2009.

89. Koves TR, Ussher JR, Noland RC, Slentz D, Mosedale M, Ilkayeva O, Bain J, Stevens R, Dyck JR, Newgard CB, Lopaschuk GD, and Muoio DM. Mitochondrial overload and incomplete fatty acid oxidation contribute to skeletal muscle insulin resistance. Cell Metab 7: 45-56, 2008.

90. Kudin AP, Malinska D, and Kunz WS. Sites of generation of reactive oxygen species in homogenates of brain tissue determined with the use of respiratory substrates and inhibitors. Biochim Biophys Acta 1777: 689-695, 2008.

91. Kuo DY, Chen PN, Yang SF, Chu SC, Chen CH, Kuo MH, $\mathrm{Yu} \mathrm{CH}$, and Hsieh YS. Role of reactive oxygen speciesrelated enzymes in neuropeptide y and proopiomelanocortinmediated appetite control: a study using atypical protein kinase C knockdown. Antioxid Redox Signal 15: 2147-2159, 2011.

92. Lage R, Vazquez MJ, Varela L, Saha AK, Vidal-Puig A, Nogueiras R, Dieguez C, and Lopez M. Ghrelin effects on neuropeptides in the rat hypothalamus depend on fatty acid metabolism actions on BSX but not on gender. FASEB J 24: 2670-2679, 2010.

93. Lam TK, Schwartz GJ, and Rossetti L. Hypothalamic sensing of fatty acids. Nat Neurosci 8: 579-584, 2005.

94. Lan F, Cacicedo JM, Ruderman N, and Ido Y. SIRT1 modulation of the acetylation status, cytosolic localization, and activity of LKB1. Possible role in AMP-activated protein kinase activation. J Biol Chem 283: 27628-27635, 2008.

95. Le Foll C, Irani BG, Magnan C, Dunn-Meynell AA, and Levin BE. Characteristics and mechanisms of hypothalamic neuronal fatty acid sensing. Am J Physiol Regul Integr Comp Physiol 297: R655-R664, 2009.

96. Le May C, Cauzac M, Diradourian C, Perdereau D, Girard J, Burnol AF, and Pegorier JP. Fatty acids induce L-CPT I gene expression through a PPARalpha-independent mechanism in rat hepatoma cells. J Nutr 135: 2313-2319, 2005.

97. Lee AH, Scapa EF, Cohen DE, and Glimcher LH. Regulation of hepatic lipogenesis by the transcription factor XBP1. Science 320: 1492-1496, 2008.

98. Leonardsson G, Steel JH, Christian M, Pocock V, Milligan S, Bell J, So PW, Medina-Gomez G, Vidal-Puig A, White R, and Parker MG. Nuclear receptor corepressor RIP140 regulates fat accumulation. Proc Natl Acad Sci U S A 101: 84378442, 2004.

99. Levin BE. Metabolic sensors: viewing glucosensing neurons from a broader perspective. Physiol Behav 76: 397-401, 2002.

100. Loh K, Deng H, Fukushima A, Cai X, Boivin B, Galic S, Bruce C, Shields BJ, Skiba B, Ooms LM, Stepto N, Wu B, Mitchell CA, Tonks NK, Watt MJ, Febbraio MA, Crack PJ, Andrikopoulos S, and Tiganis T. Reactive oxygen species enhance insulin sensitivity. Cell Metab 10: 260-272, 2009.

101. Louet JF, Chatelain F, Decaux JF, Park EA, Kohl C, Pineau T, Girard J, and Pegorier JP. Long-chain fatty acids regulate liver carnitine palmitoyltransferase I gene (L-CPT I) expression through a peroxisome-proliferator-activated receptor alpha (PPARalpha)-independent pathway. Biochem J 354: 189-197, 2001.

102. Lowell BB and Shulman GI. Mitochondrial dysfunction and type 2 diabetes. Science 307: 384-387, 2005.

103. Lumeng CN, Bodzin JL, and Saltiel AR. Obesity induces a phenotypic switch in adipose tissue macrophage polarization. J Clin Invest 117: 175-184, 2007.
104. Lumeng CN, Maillard I, and Saltiel AR. T-ing up inflammation in fat. Nat Med 15: 846-847, 2009.

105. Machann J, Bachmann OP, Brechtel K, Dahl DB, Wietek B, Klumpp B, Haring HU, Claussen CD, Jacob S, and Schick F. Lipid content in the musculature of the lower leg assessed by fat selective MRI: intra- and interindividual differences and correlation with anthropometric and metabolic data. J Magn Reson Imaging 17: 350-357, 2003.

106. Mailloux RJ and Harper ME. Uncoupling proteins and the control of mitochondrial reactive oxygen species production. Free Radic Biol Med 51: 1106-1115, 2011.

107. Mathis D and Shoelson SE. Immunometabolism: an emerging frontier. Nat Rev Immunol 11: 81, 2011.

108. McCune SA and Harris RA. Mechanism responsible for 5(tetradecyloxy)-2-furoic acid inhibition of hepatic lipogenesis. J Biol Chem 254: 10095-10101, 1979.

109. McGarry JD and Brown NF. The mitochondrial carnitine palmitoyltransferase system. From concept to molecular analysis. Eur J Biochem 244: 1-14, 1997.

110. Mera P, Bentebibel A, Lopez-Vinas E, Cordente AG, Gurunathan C, Sebastian D, Vazquez I, Herrero L, Ariza X, Gomez-Puertas P, Asins G, Serra D, Garcia J, and Hegardt FG. C75 is converted to C75-CoA in the hypothalamus, where it inhibits carnitine palmitoyltransferase 1 and decreases food intake and body weight. Biochem Pharmacol 77: 1084-1095, 2009.

111. Michan S and Sinclair D. Sirtuins in mammals: insights into their biological function. Biochem J 404: 1-13, 2007.

112. Miele L, Grieco A, Armuzzi A, Candelli M, Forgione A, Gasbarrini A, and Gasbarrini G. Hepatic mitochondrial beta-oxidation in patients with nonalcoholic steatohepatitis assessed by 13C-octanoate breath test. Am J Gastroenterol 98: 2335-2336, 2003.

113. Migrenne S, Le Foll C, Levin BE, and Magnan C. Brain lipid sensing and nervous control of energy balance. Diabetes Metab 37: 83-88, 2011.

114. Minnich A, Tian N, Byan L, and Bilder G. A potent PPARalpha agonist stimulates mitochondrial fatty acid beta-oxidation in liver and skeletal muscle. Am J Physiol Endocrinol Metab 280: E270-E279, 2001.

115. Minokoshi Y, Alquier T, Furukawa N, Kim YB, Lee A, Xue B, Mu J, Foufelle F, Ferre P, Birnbaum MJ, Stuck BJ, and Kahn BB. AMP-kinase regulates food intake by responding to hormonal and nutrient signals in the hypothalamus. Nature 428: 569-574, 2004.

116. Mollica MP, Iossa S, Liverini G, and Soboll S. Steady state changes in mitochondrial electrical potential and proton gradient in perfused liver from rats fed a high fat diet. Mol Cell Biochem 178: 213-217, 1998.

117. Monsenego J, Mansouri A, Akkaoui M, Lenoir V, Esnous C, Fauveau V, Tavernier V, Girard J, and Prip-Buus C. Enhancing liver mitochondrial fatty acid oxidation capacity in obese mice improves insulin sensitivity independently of hepatic steatosis. J Hepatol 56: 632-639, 2012.

118. Morillas M, Gomez-Puertas P, Bentebibel A, Selles E, Casals N, Valencia A, Hegardt FG, Asins G, and Serra D. Identification of conserved amino acid residues in rat liver carnitine palmitoyltransferase I critical for malonyl-CoA inhibition. Mutation of methionine 593 abolishes malonylCoA inhibition. J Biol Chem 278: 9058-9063, 2003.

119. Muoio DM. Intramuscular triacylglycerol and insulin resistance: guilty as charged or wrongly accused? Biochim Biophys Acta 1801: 281-288, 2010.

120. Muoio DM and Koves TR. Skeletal muscle adaptation to fatty acid depends on coordinated actions of the PPARs 
and PGC1 alpha: implications for metabolic disease. Appl Physiol Nutr Metab 32: 874-883, 2007.

121. Muoio DM and Neufer PD. Lipid-induced mitochondrial stress and insulin action in muscle. Cell Metab 15: 595-605, 2012.

122. Murphy MP. How mitochondria produce reactive oxygen species. Biochem J 417: 1-13, 2009.

123. Nakamuta M, Kohjima M, Morizono S, Kotoh K, Yoshimoto T, Miyagi I, and Enjoji M. Evaluation of fatty acid metabolism-related gene expression in nonalcoholic fatty liver disease. Int J Mol Med 16: 631-635, 2005.

124. Nedergaard J, Bengtsson T, and Cannon B. Unexpected evidence for active brown adipose tissue in adult humans. Am J Physiol Endocrinol Metab 293: E444-E452, 2007.

125. Nguyen KD, Qiu Y, Cui X, Goh YP, Mwangi J, David T, Mukundan L, Brombacher F, Locksley RM, and Chawla A. Alternatively activated macrophages produce catecholamines to sustain adaptive thermogenesis. Nature 480: 104-108, 2011.

126. O'Neil PM, Smith SR, Weissman NJ, Fidler MC, Sanchez M, Zhang J, Raether B, Anderson CM, and Shanahan WR. Randomized placebo-controlled clinical trial of lorcaserin for weight loss in type 2 diabetes mellitus: The BLOOMDM Study. Obesity 20: 1426-1436, 2012.

127. Obici S, Feng Z, Arduini A, Conti R, and Rossetti L. Inhibition of hypothalamic carnitine palmitoyltransferase-1 decreases food intake and glucose production. Nat Med 9: 756-761, 2003.

128. Obici S, Feng Z, Morgan K, Stein D, Karkanias G, and Rossetti L. Central administration of oleic acid inhibits glucose production and food intake. Diabetes 51: 271-275, 2002.

129. Olefsky JM and Glass CK. Macrophages, inflammation, and insulin resistance. Annu Rev Physiol 72: 219-246, 2010.

130. Orellana-Gavalda JM, Herrero L, Malandrino MI, Paneda A, Sol Rodriguez-Pena M, Petry H, Asins G, Van Deventer S, Hegardt FG, and Serra D. Molecular therapy for obesity and diabetes based on a long-term increase in hepatic fattyacid oxidation. Hepatology 53: 821-832, 2011.

131. Ortega FJ, Jilkova ZM, Moreno-Navarrete JM, Pavelka S, Rodriguez-Hermosa JI, Kopeck Ygrave J, and FernandezReal JM. Type I iodothyronine 5'-deiodinase mRNA and activity is increased in adipose tissue of obese subjects. Int J Obes 36: 320-324, 2011.

132. Ozcan U, Cao Q, Yilmaz E, Lee AH, Iwakoshi NN, Ozdelen E, Tuncman G, Gorgun C, Glimcher LH, and Hotamisligil GS. Endoplasmic reticulum stress links obesity, insulin action, and type 2 diabetes. Science 306: 457-461, 2004.

133. Park EA, Mynatt RL, Cook GA, and Kashfi K. Insulin regulates enzyme activity, malonyl-CoA sensitivity and mRNA abundance of hepatic carnitine palmitoyltransferase-I. Biochem J 310: 853-858, 1995.

134. Paterson JM, Morton NM, Fievet C, Kenyon CJ, Holmes MC, Staels B, Seckl JR, and Mullins JJ. Metabolic syndrome without obesity: Hepatic overexpression of 11betahydroxysteroid dehydrogenase type 1 in transgenic mice. Proc Natl Acad Sci U S A 101: 7088-7093, 2004.

135. Pillai VB, Sundaresan NR, Kim G, Gupta M, Rajamohan SB, Pillai JB, Samant S, Ravindra PV, Isbatan A, and Gupta MP. Exogenous NAD blocks cardiac hypertrophic response via activation of the SIRT3-LKB1-AMP-activated kinase pathway. J Biol Chem 285: 3133-3144, 2010.

136. Pissios P and Maratos-Flier E. More than satiety: central serotonin signaling and glucose homeostasis. Cell Metab 6: 345-347, 2007.
137. Pizer ES, Jackisch C, Wood FD, Pasternack GR, Davidson $\mathrm{NE}$, and Kuhajda FP. Inhibition of fatty acid synthesis induces programmed cell death in human breast cancer cells. Cancer Res 56: 2745-2747, 1996.

138. Price N, van der Leij F, Jackson V, Corstorphine C, Thomson R, Sorensen A, and Zammit V. A novel brainexpressed protein related to carnitine palmitoyltransferase I. Genomics 80: 433-442, 2002.

139. Ritov VB, Menshikova EV, Azuma K, Wood R, Toledo FG, Goodpaster BH, Ruderman NB, and Kelley DE. Deficiency of electron transport chain in human skeletal muscle mitochondria in type 2 diabetes mellitus and obesity. Am J Physiol Endocrinol Metab 298: E49-E58, 2009

140. Rochford JJ, Myers MG, Jr., and Heisler LK. Setting the tone: reactive oxygen species and the control of appetitive melanocortin neurons. Cell Metab 14: 573-574, 2011.

141. Roman EA, Reis D, Romanatto T, Maimoni D, Ferreira EA, Santos GA, Torsoni AS, Velloso LA, and Torsoni MA. Central leptin action improves skeletal muscle AKT, AMPK, and PGC1 alpha activation by hypothalamic PI3Kdependent mechanism. Mol Cell Endocrinol 314: 62-69, 2010.

142. Rosen ED and Spiegelman BM. Adipocytes as regulators of energy balance and glucose homeostasis. Nature 444: 847853, 2006.

143. Saito M, Okamatsu-Ogura Y, Matsushita M, Watanabe K, Yoneshiro T, Nio-Kobayashi J, Iwanaga T, Miyagawa M, Kameya T, Nakada K, Kawai Y, and Tsujisaki M. High incidence of metabolically active brown adipose tissue in healthy adult humans: effects of cold exposure and adiposity. Diabetes 58: 1526-1531, 2009.

144. Samuel VT, Petersen KF, and Shulman GI. Lipid-induced insulin resistance: unravelling the mechanism. Lancet 375: 2267-2277, 2010.

145. Samuel VT and Shulman GI. Mechanisms for insulin resistance: common threads and missing links. Cell 148: 852871, 2012.

146. Savage DB, Choi CS, Samuel VT, Liu ZX, Zhang D, Wang A, Zhang XM, Cline GW, Yu XX, Geisler JG, Bhanot S, Monia BP, and Shulman GI. Reversal of diet-induced hepatic steatosis and hepatic insulin resistance by antisense oligonucleotide inhibitors of acetyl-CoA carboxylases 1 and 2. J Clin Invest 116: 817-824, 2006.

147. Schenk S, Saberi M, and Olefsky JM. Insulin sensitivity: modulation by nutrients and inflammation. J Clin Invest 118: 2992-3002, 2008.

148. Schug TT and Li X. Sirtuin 1 in lipid metabolism and obesity. Ann Med 43: 198-211, 2011.

149. Sebastian D, Herrero L, Serra D, Asins G, and Hegardt FG. CPT I overexpression protects L6E9 muscle cells from fatty acid-induced insulin resistance. Am J Physiol Endocrinol Metab 292: E677-E686, 2007.

150. Serviddio G, Giudetti AM, Bellanti F, Priore P, Rollo T, Tamborra R, Siculella L, Vendemiale G, Altomare E, and Gnoni GV. Oxidation of hepatic carnitine palmitoyl transferase-I (CPT-I) impairs fatty acid beta-oxidation in rats fed a methionine-choline deficient diet. PloS One 6: e24084, 2011.

151. Shoelson SE, Herrero L, and Naaz A. Obesity, inflammation, and insulin resistance. Gastroenterology 132: 2169-2180, 2007.

152. Shulman GI, Rothman DL, Jue T, Stein P, DeFronzo RA, and Shulman RG. Quantitation of muscle glycogen synthesis in normal subjects and subjects with non-insulindependent diabetes by $13 \mathrm{C}$ nuclear magnetic resonance spectroscopy. N Engl J Med 322: 223-228, 1990. 
153. Simoneau JA, Veerkamp JH, Turcotte LP, and Kelley DE. Markers of capacity to utilize fatty acids in human skeletal muscle: relation to insulin resistance and obesity and effects of weight loss. FASEB J 13: 2051-2060, 1999.

154. Solinas G and Karin M. JNK1 and IKKbeta: molecular links between obesity and metabolic dysfunction. FASEB J 24: 2596-2611, 2010.

155. Starley BQ, Calcagno CJ, and Harrison SA. Nonalcoholic fatty liver disease and hepatocellular carcinoma: a weighty connection. Hepatology 51: 1820-1832, 2010.

156. Steyn FJ, Leong JW, Huang L, Tan HY, Xie TY, Nelson C, Waters MJ, Veldhuis JD, Epelbaum J, and Chen C. GH does not modulate the early fasting-induced release of free fatty acids in mice. Endocrinology 153: 273-282, 2012.

157. Sun K, Kusminski CM, and Scherer PE. Adipose tissue remodeling and obesity. J Clin Invest 121: 2094-2101, 2011.

158. Sunny NE, Parks EJ, Browning JD, and Burgess SC. Excessive hepatic mitochondrial TCA cycle and gluconeogenesis in humans with nonalcoholic fatty liver disease. Cell Metab 14: 804-810, 2011.

159. Taube A, Eckardt K, and Eckel J. Role of lipid-derived mediators in skeletal muscle insulin resistance. Am J Physiol Endocrinol Metab 297: E1004-E1012, 2009.

160. Taubes G. Insulin resistance. Prosperity's plague. Science 325: 256-260, 2009.

161. Tiniakos DG, Vos MB, and Brunt EM. Nonalcoholic fatty liver disease: pathology and pathogenesis. Annu Rev Pathol 5: 145-171, 2010.

162. Tseng YH, Cypess AM, and Kahn CR. Cellular bioenergetics as a target for obesity therapy. Nat Rev Drug Discov 9: 465-482, 2010.

163. Tunstall RJ, Mehan KA, Wadley GD, Collier GR, Bonen A, Hargreaves M, and Cameron-Smith D. Exercise training increases lipid metabolism gene expression in human skeletal muscle. Am J Physiol Endocrinol Metab 283: E66-E72, 2002.

164. Turner N, Bruce CR, Beale SM, Hoehn KL, So T, Rolph MS, and Cooney GJ. Excess lipid availability increases mitochondrial fatty acid oxidative capacity in muscle: evidence against a role for reduced fatty acid oxidation in lipidinduced insulin resistance in rodents. Diabetes 56: 20852092, 2007.

165. van Marken Lichtenbelt WD, Vanhommerig JW, Smulders NM, Drossaerts JM, Kemerink GJ, Bouvy ND, Schrauwen $\mathrm{P}$, and Teule GJ. Cold-activated brown adipose tissue in healthy men. N Engl J Med 360: 1500-1508, 2009.

166. Velasco G, Geelen MJ, and Guzman M. Control of hepatic fatty acid oxidation by $5^{\prime}$-AMP-activated protein kinase involves a malonyl-CoA-dependent and a malonyl-CoAindependent mechanism. Arch Biochem Biophys 337: 169175, 1997.

167. Velasquez DA, Martinez G, Romero A, Vazquez MJ, Boit KD, Dopeso-Reyes IG, Lopez M, Vidal A, Nogueiras R, and Dieguez C. The central Sirtuin 1/p53 pathway is essential for the orexigenic action of ghrelin. Diabetes 60: 1177-1185, 2011.

168. Virtanen KA, Lidell ME, Orava J, Heglind M, Westergren R, Niemi T, Taittonen M, Laine J, Savisto NJ, Enerback S, and Nuutila P. Functional brown adipose tissue in healthy adults. N Engl J Med 360: 1518-1525, 2009.

169. Virtue $S$ and Vidal-Puig A. Adipose tissue expandability, lipotoxicity and the Metabolic Syndrome-an allostatic perspective. Biochim Biophys Acta 1801: 338-349, 2010.
170. Wagner BA, Buettner GR, and Burns CP. Free radicalmediated lipid peroxidation in cells: oxidizability is a function of cell lipid bis-allylic hydrogen content. Biochemistry 33: 4449-4453, 1994.

171. Weisberg SP, McCann D, Desai M, Rosenbaum M, Leibel RL, and Ferrante AW, Jr. Obesity is associated with macrophage accumulation in adipose tissue. J Clin Invest 112: 1796-1808, 2003.

172. Whittle AJ, Carobbio S, Martins L, Slawik M, Hondares E, Vazquez MJ, Morgan D, Csikasz RI, Gallego R, RodriguezCuenca S, Dale M, Virtue S, Villarroya F, Cannon B, Rahmouni K, Lopez M, and Vidal-Puig A. BMP8B increases brown adipose tissue thermogenesis through both central and peripheral actions. Cell 149: 871-885, 2012.

173. Wolfgang MJ, Cha SH, Sidhaye A, Chohnan S, Cline G, Shulman GI, and Lane MD. Regulation of hypothalamic malonyl-CoA by central glucose and leptin. Proc Natl Acad Sci U S A 104: 19285-19290, 2007.

174. Woods A, Johnstone SR, Dickerson K, Leiper FC, Fryer LG, Neumann D, Schlattner U, Wallimann T, Carlson M, and Carling D. LKB1 is the upstream kinase in the AMPactivated protein kinase cascade. Curr Biol 13: 2004-2008, 2003.

175. Yamazaki N, Shinohara Y, Shima A, and Terada H. High expression of a novel carnitine palmitoyltransferase I like protein in rat brown adipose tissue and heart: isolation and characterization of its cDNA clone. FEBS Lett 363: 41-45, 1995.

176. Yeh LA, Lee KH, and Kim KH. Regulation of rat liver acetyl-CoA carboxylase. Regulation of phosphorylation and inactivation of acetyl-CoA carboxylase by the adenylate energy charge. J Biol Chem 255: 2308-2314, 1980.

177. Yue JT and Lam TK. Lipid sensing and insulin resistance in the brain. Cell Metab 15: 646-655, 2012.

178. Zeng L, Lu M, Mori K, Luo S, Lee AS, Zhu Y, and Shyy JY. ATF6 modulates SREBP2-mediated lipogenesis. EMBO J 23: 950-958, 2004.

179. Zhang Y, Proenca R, Maffei M, Barone M, Leopold L, and Friedman JM. Positional cloning of the mouse obese gene and its human homologue. Nature 372: 425-432, 1994.

180. Zhou G, Myers R, Li Y, Chen Y, Shen X, Fenyk-Melody J, Wu M, Ventre J, Doebber T, Fujii N, Musi N, Hirshman MF, Goodyear LJ, and Moller DE. Role of AMP-activated protein kinase in mechanism of metformin action. J Clin Invest 108: 1167-1174, 2001.

181. Zingaretti MC, Crosta F, Vitali A, Guerrieri M, Frontini A, Cannon B, Nedergaard J, and Cinti S. The presence of UCP1 demonstrates that metabolically active adipose tissue in the neck of adult humans truly represents brown adipose tissue. FASEB J 23: 3113-3120, 2009.

Address correspondence to: Dr. Laura Herrero Department of Biochemistry and Molecular Biology School of Pharmacy

University of Barcelona Av. Diagonal, 643 E-08028 Barcelona Spain

E-mail: lherrero@ub.edu

Date of first submission to ARS Central, August 11, 2012; date of acceptance, August 19, 2012. 


$\begin{aligned} & \text { Abbreviations Used } \\ \mathrm{ACC} & =\text { acetyl-CoA carboxylase } \\ \mathrm{AgRP} & =\text { agouti-related protein } \\ \mathrm{AMPK} & =\mathrm{AMP} \text {-activated protein kinase } \\ \mathrm{BAT} & =\text { brown adipose tissue } \\ \mathrm{BMI} & =\text { body mass index } \\ \mathrm{CACT} & =\text { acylcarnitine translocase } \\ \mathrm{CPT} 1 & =\text { carnitine palmitoyltransferase } 1 \\ \mathrm{CPT} 1 \mathrm{~A} & =\text { liver CPT1 } \\ \mathrm{CT} & =\text { computed tomography } \\ \mathrm{DAG} & =\text { diacylglycerol } \\ \mathrm{ETC} & =\text { electron transport chain } \\ \mathrm{FA} & =\text { fatty acid } \\ \mathrm{FAO} & =\text { fatty acid oxidation } \\ \mathrm{FAS} & =\text { fatty acid synthase } \\ \mathrm{FFA} & =\text { free fatty acid }\end{aligned}$

$\begin{aligned} \text { FGF21 } & =\text { fibroblast growth factor } 21 \\ \mathrm{HFD} & =\text { high-fat diet } \\ \mathrm{IMC} & =\text { intramyocellular } \\ \mathrm{LCFA}-\mathrm{CoA} & =\text { long-chain fatty acid-CoA } \\ \mathrm{MCD} & =\text { malonyl-CoA decarboxylase } \\ \mathrm{NAFLD} & =\text { nonalcoholic fatty liver disease } \\ \mathrm{NASH} & =\text { nonalcoholic steatohepatitis } \\ \mathrm{NPY} & =\text { neuropeptide } \mathrm{Y} \\ \mathrm{PET} & =\text { positron-emission tomography } \\ \mathrm{ROS} & =\text { reactive oxygen species } \\ \mathrm{SkM} & =\text { skeletal muscle } \\ \mathrm{TCA} & =\text { tricarboxylic acid } \\ \mathrm{TG} & =\text { triglyceride } \\ \mathrm{UCPS} & =\text { uncoupling proteins } \\ \mathrm{UPR} & =\text { uncoupled protein response } \\ \mathrm{WAT} & =\text { white adipose tissue }\end{aligned}$

